\title{
Thermal modelling of new Li-ion cell design modifications
}

\author{
M. Sievers · U. Sievers · S.S. Mao
}

Received: 30 July 2010 / Published online: 11 September 2010

(C) The Author(s) 2010. This article is published with open access at Springerlink.com

\begin{abstract}
The effects of material and design modifications on the temperature distribution of $\mathrm{Li}$-ion cells are simulated numerically. A two-dimensional anisotropic cylindrical coordinate model with linear triangular finite elements is used to simulate the steady-state temperature distribution within the cell. The cell's material and geometry are changed. New cell materials are investigated for thermal performance: a negative electrode of variously-oriented carbon nanotubes, as well as separators made of Separion, of $\mathrm{Al}_{2} \mathrm{O}_{3}$ containing $\mathrm{Cr}$ particles or of $\mathrm{BeO}$ containing $\mathrm{Be}$ and $\mathrm{Si}$ particles. The cell's diameter and length are varied. A new cell design with an internal cooling tube is proposed. The effect of cooling tube diameter upon cell temperature and the energy efficiency of cooling are investigated. This simple design change significantly improves the temperature distribution at marginal cost.
\end{abstract}

\section{Berechnung der Temperaturverteilung in konstruktiv veränderten Li-Ionen-Zellen}

Zusammenfassung Der Einfluss neuer Batteriematerialien und konstruktiver Änderungen auf die Temperaturverteilung

M. Sievers · S.S. Mao

Department of Mechanical Engineering, University of California at Berkeley, 6167 Etcheverry Hall, Berkeley, CA 94720-1740, USA

Present address:

M. Sievers

Department of Mechanical Engineering, Hamburg University of

Technology, 21071 Hamburg, Germany

U. Sievers $(\bowtie)$

Department of Mechanical Engineering, Hamburg University of Applied Sciences, Berliner Tor 21, 20099 Hamburg, Germany

e-mail: uwe.sievers@haw-hamburg.de in Li-Ionen-Zellen wird numerisch simuliert. Ein zweidimensionales, anisotropes Modell mit linearen dreieckigen Finiten-Elementen wird zur Simulation der stationären Temperaturverteilung in der Zelle eingesetzt. Als neue Batteriematerialien werden eine negative Elektrode aus KohlenstoffNanoröhrchen verschiedener Orientierungen sowie Separatoren aus Separion, $\mathrm{Al}_{2} \mathrm{O}_{3}$ mit Cr-Praktikeln und $\mathrm{BeO}$ mit Be- und Si-Partikeln untersucht. Zelldurchmesser und länge werden variiert. Eine neue Zellkonstruktion mit einem inneren Kühlrohr wird vorgestellt. Der Einfluss des Kühlrohrdurchmessers auf die Temperaturverteilung in der Zelle und die Energieeffizienz der Kühlung werden untersucht. Diese einfache konstruktive Änderung verbessert die Temperaturverteilung signifikant bei geringen Mehrkosten.

\begin{tabular}{|c|c|}
\hline \multicolumn{2}{|c|}{ List of $s$} \\
\hline$A$ & area $\left(\mathrm{m}^{2}\right)$ \\
\hline$A_{\text {cross }}$ & cross-sectional area $\left(\mathrm{m}^{2}\right)$ \\
\hline$A_{s}$ & heat transfer surface area $\left(\mathrm{m}^{2}\right)$ \\
\hline$c_{p}$ & $\begin{array}{l}\text { specific heat capacity at constant pressure } \\
\left(\mathrm{kJ} \mathrm{kg}^{-1} \mathrm{~K}^{-1}\right)\end{array}$ \\
\hline$D_{s}$ & internal cooling tube diameter $(\mathrm{m})$ \\
\hline$G_{l}$ & constant in infinite eigenvalue series (-) \\
\hline$g$ & heat generation $\left(\mathrm{W} \mathrm{m}^{-3}\right)$ \\
\hline$h$ & heat transfer coefficient $\left(\mathrm{W} \mathrm{m}^{-2} \mathrm{~K}^{-1}\right)$ \\
\hline$I$ & electric current $(\mathrm{A})$ \\
\hline$k$ & thermal conductivity $\left(\mathrm{W} \mathrm{m}^{-1} \mathrm{~K}^{-1}\right.$ ) \\
\hline$L$ & $\begin{array}{l}\text { length, length of the cell, characteristic } \\
\text { length }(\mathrm{m})\end{array}$ \\
\hline$n$ & number of elements in axial direction (-) \\
\hline$\dot{q}$ & heat flow (W) \\
\hline$\dot{q}_{s}^{\prime \prime}$ & heat flux at surface $\left(\mathrm{W} \mathrm{m}^{-2}\right)$ \\
\hline$r$ & radius, radial coordinate $(\mathrm{m})$ \\
\hline$r_{s}$ & internal cooling tube radius (m) \\
\hline$r_{1}$ & outer radius of cell winding $(\mathrm{m})$ \\
\hline
\end{tabular}




$\begin{array}{ll}r_{2} & \text { outer radius of cell casing }(\mathrm{m}) \\ r^{+} & \text {dimensionless radial coordinate }(-) \\ T & \text { Celsius temperature }\left({ }^{\circ} \mathrm{C}\right) \\ T & \text { thermodynamic temperature in }(6)(\mathrm{K}) \\ T_{m} & \text { mean mixed temperature }\left({ }^{\circ} \mathrm{C}\right) \\ T & (\text { volume-weighted) mean temperature } \\ & \left({ }^{\circ} \mathrm{C}\right) \\ U & \text { voltage }(\mathrm{V}) \\ u & \text { flow velocity }\left(\mathrm{m} \mathrm{s}^{-1}\right) \\ u_{r e f} & \text { reference flow velocity }\left(\mathrm{m} \mathrm{s}^{-1}\right) \\ V & \text { volume }\left(\mathrm{m}^{3}\right) \\ x & \text { axial coordinate }(\mathrm{m}) \\ x^{+} & \text {dimensionless axial coordinate }(-)\end{array}$

\section{Greek letters}

$\Delta$

$\Theta$

$\lambda_{l}$

$v$

$\rho$

$\xi$

$\xi^{+}$

\section{Subscripts}

$\begin{array}{ll}\text { cond } & \text { due to conduction } \\ \text { conv } & \text { due to convection } \\ \text { crit } & \text { critical radius } \\ \text { e } & \text { electrolyte, inlet } \\ \text { f } & \text { fluid } \\ \text { max } & \text { maximum } \\ \text { OC } & \text { open circuit } \\ \text { s } & \text { surface } \\ \text { se } & \text { surface at inlet } \\ \text { step } & \text { for a step change } \\ 1 & \text { inner cylinder, cell winding } \\ 2 & \text { outer cylinder, cell casing } \\ \infty & \text { state of surroundings }\end{array}$

\section{Dimensionless numbers}

$\begin{array}{ll}N u=h L / k & \text { Nußelt number } \\ P e=u L \rho c_{p} / k & \text { Péclet number } \\ \operatorname{Pr}=v \rho c_{p} / k & \text { Prandtl number } \\ \operatorname{Re}=u L / v & \text { Reynolds number }\end{array}$

\section{Introduction}

Since the market introduction of hybrid electric vehicles (HEV), the batteries must fulfill ever higher technical specifications. Only a battery with sufficiently high energy and power densities can fulfill the charge and discharge requirements for a hybrid electric vehicle. A discharge (charge) rate between 10 and $15 \mathrm{C}$-full discharge (charge) within 4 to 6 minutes - should be feasible without degrading battery performance or battery life unacceptably. One emerging technology which fulfills these requirements is the Li-ion cell, already widely used in consumer electronics. Its use in hybrid electric vehicles would improve existing hybrid designs and lead to the development of HEVs which use a higher portion of electric energy. Not only the electrical management system which controls battery charge and discharge must be redesigned for Li-ion cells; a new thermal management system to control battery temperature must also be developed, as the trend to high power densities results in more heat generated within a smaller volume. A temperature increase of $15^{\circ} \mathrm{C}$ reduces the life of a Li-ion cell by about $50 \%[1,2]$. The stated aim of FreedomCAR and the U.S. Advanced Battery Consortium is to achieve an HEV battery life of 15 years by 2010 [3]. An improved thermal management to extend battery life is required [4]. Various thermal management architectures have been proposed for this purpose $[5,6]$.

A wide variety of Li-ion cells is commercially available. Different cell types are usually named according to their active materials. In principle, Li-ion cells function in the same manner as galvanic elements: The two electrodes, which are separated by a thin membrane, the so-called separator, differ in electrochemical potential, and are thus driven to exchange electrons. In the completely discharged state, the lithium is intercalated within the positive electrode. When the positive and negative electrode are connected to charge the cell, electrons are conducted through the external electrical connection, and $\mathrm{Li}^{+}$ions diffuse through the separator towards the negative electrode. When discharging, electrons and $\mathrm{Li}^{+}$ ions flow in the opposite direction. Further information on the electrochemistry of batteries and galvanic cells is to be found e.g. in [2].

Both cylindrical and prismatic Li-ion cells are manufactured. HEVs generally employ cylindrical cells. One standard cylindrical cell architecture (sometimes known as the spirally-wound cell) is represented in Fig. 1. The various layers are wound spirally around the inner hollow space and stabilized by a cylindrical steel casing which subjects the contents of the cell to a homogeneous pressure. The electrodes incorporate a conductor to extract the electrical power. In general, the positive and negative conductors are respectively composed of aluminum and copper alloys, whose high thermal conductivities favorably influence overall thermal performance. The positive conductor is connected to the positive terminal (left-hand side of Fig. 1), and the negative conductor is connected to the negative terminal. The steel casing is filled with a liquid electrolyte, and sealed to prevent mass transfer with the surroundings. To prevent the cell bursting at high temperature, it is fitted with 


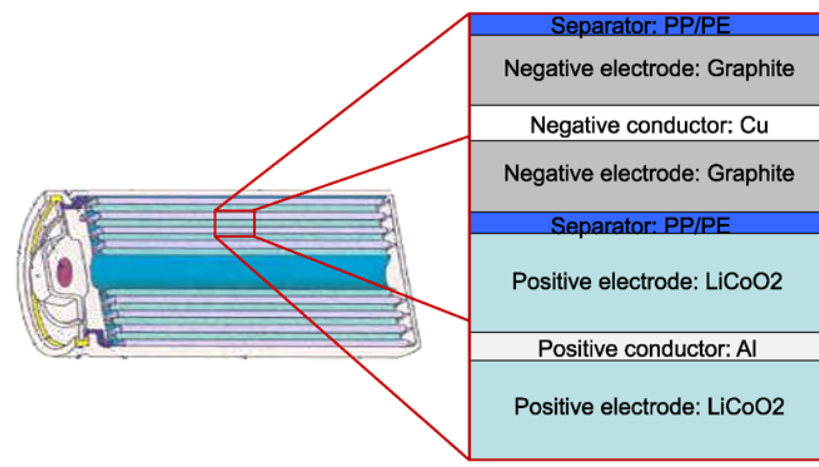

Fig. 1 Spirally wound architecture of a Li-ion cell [7]

a pressure-activated valve which releases some of the electrolyte if the pressure becomes excessively high. If the temperature exceeds a certain limit, a positive temperature coefficient element (PTC) interrupts the electrical connection until the cell temperature falls to a safe value.

This paper describes the development of a model with either constant surface temperature boundary condition or convective heat transfer boundary condition which simulates the temperature field of a single cylindrical Li-ion cell. Constant temperature boundary conditions are a good benchmark, since the resulting temperature field is equivalent to perfect heat transfer with an infinite heat transfer coefficient. The calorimetric model is used to calculate a two-dimensional steady-state temperature distribution within a cell. Finally, various means of improving temperature distribution are considered. These include the use of new cell materials and a new cell design with an internal cooling tube.

\section{Modelling}

The temperature distribution within an electrochemical cell is simulated by a cylindrical-coordinate finite element model with linear triangular elements. The finite element method and its application to heat transfer are described by Lewis et al. [8].

The model is implemented in Modelica [9], as it shall be applied in a Modelica based thermal management system simulation. The basic model has been described in previous publications [10,11]. Sievers [10] showed that the cell design needs to be changed in order to fulfill temperature restrictions. For a longitudinal flow around the cell the heat transfer problem is reduced to two dimensions. An advanced heat transfer model has been developed and implemented.

\subsection{One-dimensional cylinder model and validation}

Although the model has already been validated using the solution for a homogeneous cylinder [10], validation is now

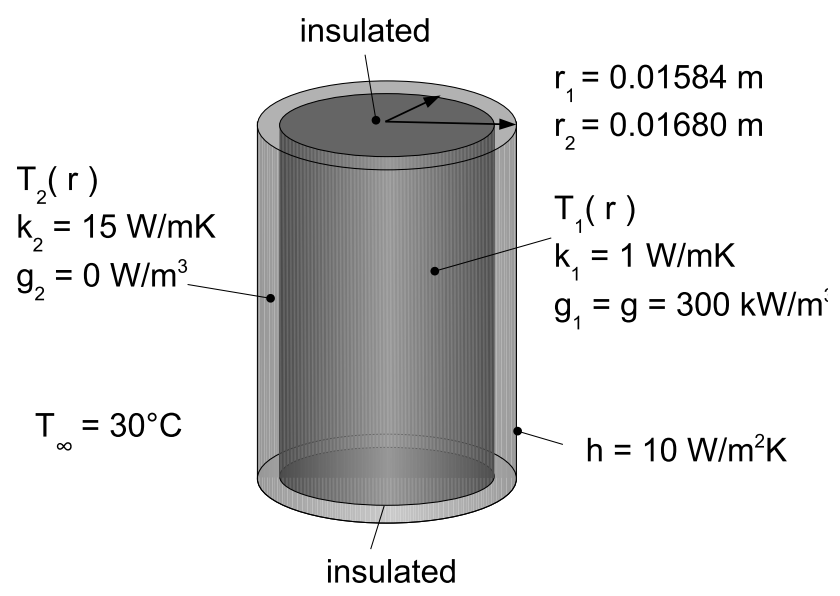

Fig. 2 One-dimensional cylinder model used for validation

extended using a more advanced analytical method. The validation scheme outlined in Fig. 2 provides additional information about the model, as it includes region 1 (cell winding) with heat generation $\mathrm{g}$ and region 2 (cell casing) without heat generation. The heat is generated in and conducted through the inner cylinder $1\left(k_{1}, r_{1}\right)$, then conducted through the outer cylinder $2\left(k_{2}, r_{2}\right)$ and transferred to the surroundings by convection with heat transfer coefficient $h$. The values chosen are close to the actual cell configuration, with the exception of the low heat transfer coefficient.

Solving the differential equation for heat conduction with convection at the cell surface for steady-state yields

$T_{1}(r)=T_{\infty}+\frac{g r_{1}^{2}}{4 k_{1}}\left[1-\left(\frac{r}{r_{1}}\right)^{2}+\frac{2 k_{1}}{k_{2}} \ln \left(\frac{r_{2}}{r_{1}}\right)+\frac{2 k_{1}}{h r_{2}}\right]$

for the inner cylinder and

$T_{2}(r)=T_{\infty}+\frac{g r_{1}^{2}}{4 k_{1}}\left[\frac{2 k_{1}}{k_{2}} \ln \left(\frac{r_{2}}{r}\right)+\frac{2 k_{1}}{h r_{2}}\right]$

for the outer cylinder.

The equivalent numerical results of the simulation model deviate by less than $0.02^{\circ} \mathrm{C}$ from the analytical results of (1) and (2). The analytical solution also indicates how cell cooling might be improved. Equations (1) and (2) include the parameters $T_{\infty}, g, k_{1}, k_{2}, r_{1}, r_{2}$ and $h$ whose values influence the temperature distribution within the cell.

The thermal conductivities $k_{1}$ and $k_{2}$ of the battery materials can be changed by modifying the material structure, e.g. at the nanoscale or by adding a component with high thermal conductivity. Various battery materials with improved thermal properties are currently under investigation, some of which are presented in Sects. 3.4 and 3.5. Temperature diagrams for different thermal conductivities $k_{1}$ of the active material are shown in Fig. 3 (left). 


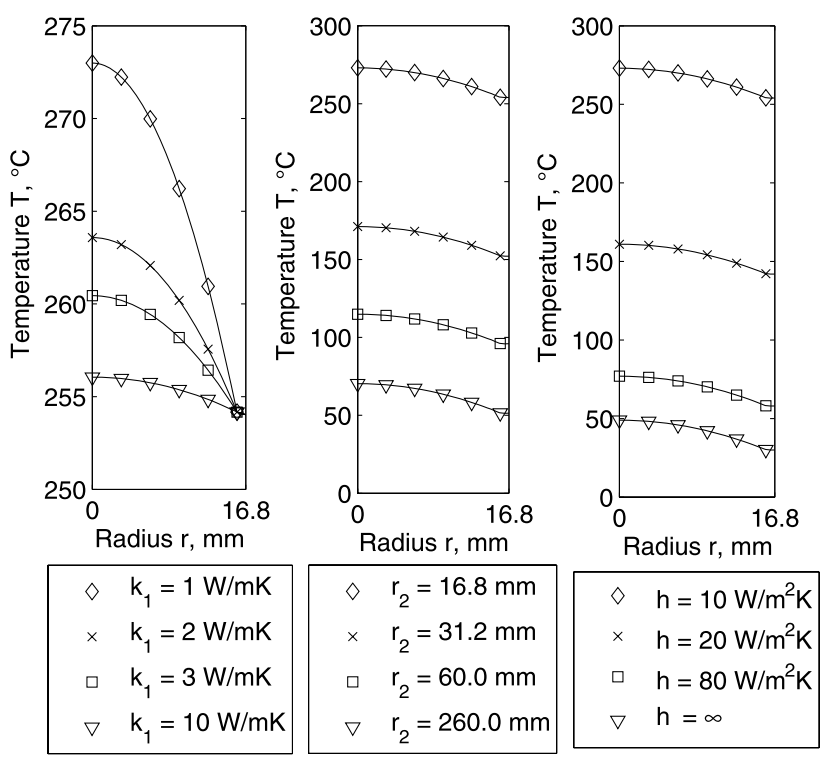

Fig. 3 Temperature of 1-D cylinder as shown in Fig. 2 for various values of thermal conductivity $k_{1}$ (left), outer radius $r_{2}$ (centre) and heat transfer coefficient $h$ (right). Values of other parameters as in Fig. 2

The temperature distribution can be improved by changing the cell geometry. An increase in outer radius $r_{2}$ without increasing $r_{1}$ increases the surface area for heat transfer and reduces the thermal resistance of convective heat transfer, if the outer radius is less than the critical outer radius

$r_{2, \text { crit }}=\frac{k_{2}}{h}$.

For the values of heat transfer coefficient $h$ and cell casing thermal conductivity $k_{2}$ given in Fig. 2, the critical outer radius is $1.50 \mathrm{~m}$. In none of the simulations, the radius exceeds the critical radius. Increasing the outer radius thus improves the cell temperature distribution. This concept of surface enlargement can be taken into account when designing the cell casing. Fins or other components which increase the surface area may prove helpful. The effect of outer radius variation is shown in Fig. 3 (centre).

Even if the heat transfer coefficient is increased, the hottest spot in the cell cannot be cooled below $49^{\circ} \mathrm{C}$ by radial heat conduction alone, see Fig. 3 (right).

For the one-dimensional model the heat transfer coefficient appears as a constant in (1) and (2) for the temperature distributions of inner and outer cylinders. The maximum temperature difference within the cell

$$
\begin{aligned}
T_{1}(0)-T_{2}\left(r_{2}\right) & =\frac{g r_{1}^{2}}{4 k_{1}}\left[1+2 \frac{k_{1}}{k_{2}} \ln \left(r_{2} / r_{1}\right)\right] \\
& =18.97^{\circ} \mathrm{C}
\end{aligned}
$$

as well as the temperature difference within the casing material

$T_{1}\left(r_{1}\right)-T_{2}\left(r_{2}\right)=\frac{g r_{1}^{2}}{2 k_{2}} \ln \left(r_{2} / r_{1}\right)=0.15^{\circ} \mathrm{C}$

are independent of the heat transfer coefficient $h$. These temperature difference values are calculated from the data of Fig. 2. The temperature difference is expected to be high within the active material, and this will be a subject of special attention in the analysis of the two-dimensional model in Sect. 3.

\subsection{Properties of the simulated cell}

The layers within the cell play an important role in the heat transfer properties and therefore determine the thermal performance of the cell. The separator layers, usually made of polypropylene (PP) or polyethylene (PE), are of relatively low thermal conductivity. The graphite negative electrode surrounds a copper $(\mathrm{Cu})$ negative conductor. The positive electrode is made of lithium cobalt dioxide $\left(\mathrm{LiCoO}_{2}\right)$ and surrounds an aluminum ( $\mathrm{Al}$ ) positive conductor.

Dimensions and properties of the cell and its windings are listed in Tables 1 and 2. There are 31 windings [10]. These windings, the hollow space inside the windings and the cell casing are modeled by 35 radial and 10 axial elements. An equivalent thermal conductivity is calculated for each winding by using series resistance connections radially and parallel resistance connections axially [10]. The result is a cell with anisotropic material properties. On average, the thermal conductivity is about 28 times higher axially than radially. These simplifications lead to a model with about 175000 equations.

\subsection{Heat source}

The internal heat source of the Li-ion cell is assumed to be homogeneous within the windings, a common assumption for thermal models [14-16]. This is true only if the influence of temperature variation within the cell can be neglected. It is also assumed that heat is generated equally in all layers. To assess the amount of heat generated $g$, Gibbard et al. [19]

Table 1 Data of the simulated cell [12]

\begin{tabular}{ll}
\hline Diameter & $33.6 \mathrm{~mm}$ \\
Length & $142.8 \mathrm{~mm}$ \\
Nominal voltage & $3.6 \mathrm{~V}$ \\
Nominal capacity & $7.5 \mathrm{Ah}$ \\
Internal resistance & $<2 \mathrm{~m} \Omega$ \\
Maximum charge/discharge current & $75 \mathrm{~A}$ \\
Operating temperature & $-30^{\circ} \mathrm{C} / 60^{\circ} \mathrm{C}$ \\
\hline
\end{tabular}



properties of the simulated cell and the layers of the windings $[2,12-15,17,18]$
Table 2 Dimensions and

\begin{tabular}{|c|c|c|c|c|c|c|c|}
\hline \multicolumn{2}{|c|}{ Component } & Material & $\begin{array}{l}\text { Length } \\
\mathrm{mm}\end{array}$ & $\begin{array}{l}\text { Outer- } \\
\text { diameter }\end{array}$ & $\begin{array}{l}\text { Thickness } \\
\mathrm{mm}\end{array}$ & Porosity & $\begin{array}{l}\text { Thermal } \\
\text { conductivity } \\
\mathrm{W} /(\mathrm{m} \mathrm{K})\end{array}$ \\
\hline \multicolumn{2}{|l|}{ Casing } & Steel 1.4541 & 142.8 & 33.60 & 0.480 & & 15 \\
\hline \multicolumn{2}{|c|}{ Winding with the following } & & 140.8 & 32.64 & 0.480 & & \\
\hline \multirow[t]{9}{*}{ layers: } & Separator & $\mathrm{PP} / \mathrm{PE}$ & 140.8 & & 0.020 & 0.50 & 0.22 \\
\hline & Negative electrode & Graphite & 140.8 & & 0.060 & 0.45 & 1.04 \\
\hline & Negative conductor & $\mathrm{Cu}$ & 140.8 & & 0.020 & & 395 \\
\hline & Negative electrode & Graphite & 140.8 & & 0.060 & 0.45 & 1.04 \\
\hline & Separator & $\mathrm{PP} / \mathrm{PE}$ & 140.8 & & 0.020 & 0.50 & 0.22 \\
\hline & Positive electrode & $\mathrm{LiCoO}_{2}$ & 140.8 & & 0.140 & 0.45 & 1.58 \\
\hline & Positive conductor & $\mathrm{Al}$ & 140.8 & & 0.020 & & 240 \\
\hline & Positive electrode & $\mathrm{LiCoO}_{2}$ & 140.8 & & 0.140 & 0.45 & 1.58 \\
\hline & Electrolyte & $\mathrm{LiPF}_{6}$ & 140.8 & & & & 0.60 \\
\hline \multicolumn{2}{|c|}{ Hollow Space } & Graphite, $\mathrm{LiPF}_{6}$ & 140.8 & 2.88 & & & 0.60 \\
\hline \multicolumn{2}{|c|}{ Negative end connector } & $\mathrm{Cu}$ & & 32.64 & 1.000 & & 395 \\
\hline \multicolumn{2}{|c|}{ Positive end connector } & $\mathrm{Al}$ & & 32.64 & 1.000 & & 240 \\
\hline
\end{tabular}

propose a formula since confirmed by Bernardi et al. [20]:

$g=g(T)=\frac{I}{V}\left(U_{O C}-U+T \frac{d U_{O C}}{d T}\right)$.

The data from $[12,14]$ permit the heat generation by a $\mathrm{LiCoO}_{2} / \mathrm{C}$ system at $35^{\circ} \mathrm{C}$ to be $g=183 \ldots 253 \mathrm{~kW} / \mathrm{m}^{3}$. These values agree approximately with measurements reported by the Argonne National Laboratories [4]. Nearly all analyses in this paper are simulated with heat generation $g=300 \mathrm{~kW} / \mathrm{m}^{3}$.

\subsection{Use of a cooling tube inside the cell}

\subsubsection{Minimum required heat transfer coefficient in the cooling tube}

The hottest zone of the cell is somewhat downstream of its centre, as is seen in the simulations described in Sect. 3. Designs which enhance heat removal from this zone reduce the maximum temperature as well as the maximum temperature difference within the cell. This paper presents a new concept for heat removal from this zone. In the standard cylindrical cell design, the cell core is occupied by a carbon electrode and electrolyte. In the new design, an axial cooling tube within the cell is created, replacing part of the carbon electrode, Fig. 4.

The relatively low Reynolds number of the flow within this small tube results in heat transfer conditions which differ greatly from perfect heat transfer at a constant temperature boundary condition, so the heat transfer model presented in Sect. 2.5 is used.

The new design must ensure that the heat flow out of the cell is higher than can be achieved by heat conduction in the

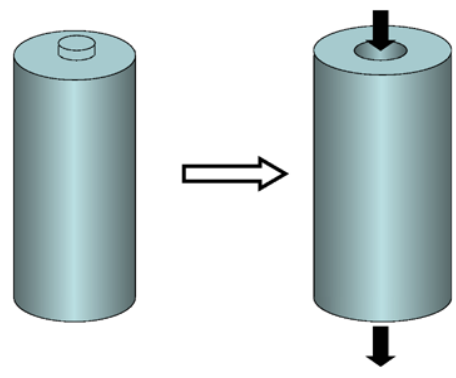

Fig. 4 Change of standard cell design (left) to design with a cooling tube (right)

standard electrolyte-soaked carbon electrode. A successful new design will achieve a lower core temperature for both forced convection and free convection within this tube of diameter $D_{s}$ and cross-sectional area $A_{\text {cross }}$. Heat flow from the core of the standard cell may be approximated by

$\dot{q}_{\text {cond }} \approx 2 k_{e} A_{\text {cross }}\left|\frac{d T}{d x}\right| \approx 2 k_{e} A_{\text {cross }} \frac{T_{\max }-T_{\text {se }}}{L / 2}$,

assuming a linear surface temperature profile, as indicated in Fig. 5. $T_{\max } \approx 42^{\circ} \mathrm{C}$ is the maximum temperature; both end caps have approximately the same temperature $T_{s e} \approx 30^{\circ} \mathrm{C}$. The axial coordinate is $\mathrm{x}$, and $\mathrm{L}$ is the cell length. In the new design, the heat removed in the tube is approximated by

$\dot{q}_{c o n v} \approx h A_{s}\left(T_{s}-T_{m}\right)$,

where $A_{s}$ is the tube surface area, $T_{s}$ the tube surface temperature and $T_{m}$ the temperature of the fluid in the tube. More heat is removed by convective heat transfer in the tube 


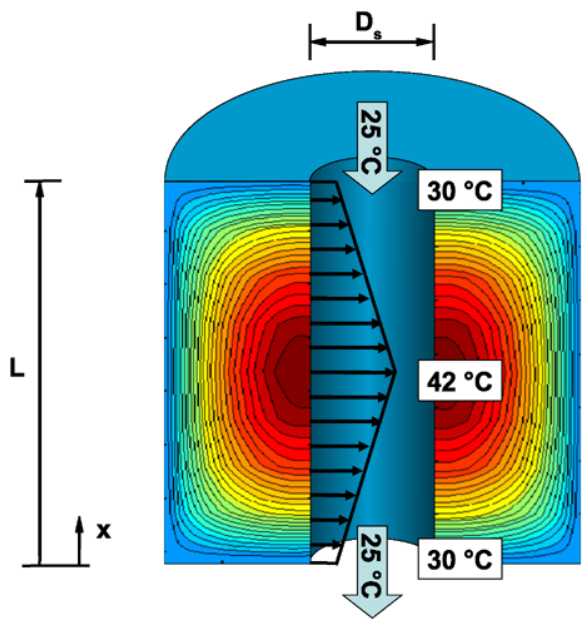

Fig. 5 Cell temperature for comparison with new cell design

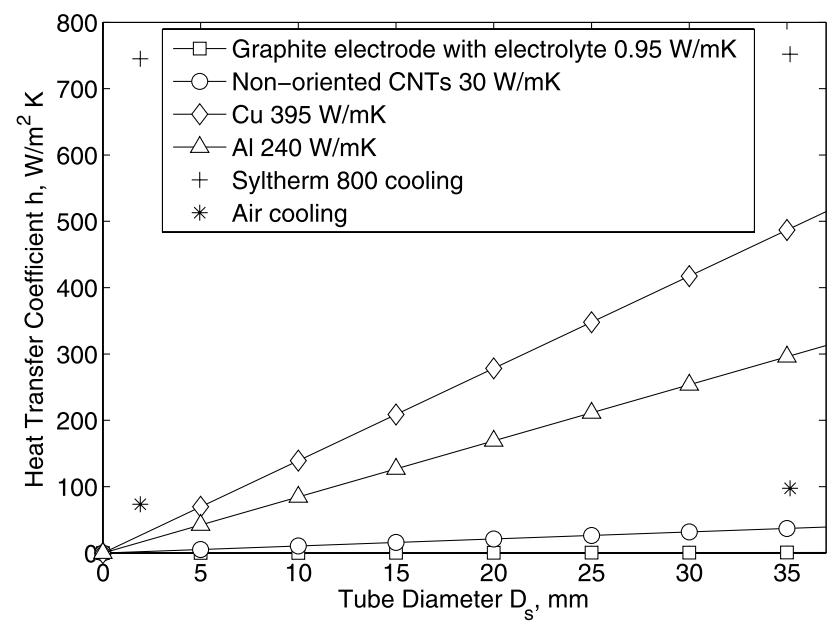

Fig. 6 Minimum cooling tube heat transfer coefficient $h$ required for improved heat removal. Results of simulations with air as a coolant with a reference flow velocity of $12 \mathrm{~m} / \mathrm{s}$ and Syltherm 800 with a reference flow velocity of $1 \mathrm{~m} / \mathrm{s}$ in the tube from Sect. 3 are included for comparison

(see (8)) than by conduction within the soaked carbon electrode (see (7)), if the following condition applies to the heat transfer coefficient in the cooling tube:

$h \geq \frac{k_{e}}{D_{s}} \frac{T_{\max }-T_{s e}}{T_{s}-T_{m}}\left(\frac{D_{s}}{L}\right)^{2}$.

The approximations neglect the temperature change of the fluid in the tube. However, this is taken into account in the simulations in Sect. 3.

Minimum useful heat transfer coefficient values are calculated according to (9) and plotted in Fig. 6 using the dimensions and thermal properties from Table 2 . The cooling tube is advantageous if the heat transfer coefficient in the tube is higher than the value shown in Fig. 6; otherwise, heat conduction within the solid material results in lower tem- peratures. For comparison four additional simulation results from Sect. 3 are shown; these are explained later.

\subsubsection{Simulated cooling tube diameters and coolant velocities}

In the following simulation, each cell geometry has the same active volume, and generates the same amount of heat, so that different solutions can be compared. In each case, the same power is used to transport the coolant through the tube and along the cell shell, resulting in different flow velocities, as determined from the Bernoulli equation for incompressible flow [21]. For external and internal flow through the tube, the coolant's pressure drop is equal. The complete calculation scheme based on [13], and resulting coolant velocities, are to be found in [22].

\subsection{Heat transfer model}

For basic simulations a heat transfer model has been developed [10] that distinguishes between free and forced convection, laminar and turbulent flow, fully-developed flow, thermal inlet flow, and thermally and hydrodynamically developing flow. This model does not take a variable wall temperature into account.

In this paper, an improved heat transfer model for variable wall temperature is introduced, first for the flow in the axial cooling tube within the cell and then for the axial flow along the cylindrical cell shell. Simulations with a convective boundary condition are applied to thermally developing flow, with a hydrodynamically fully developed flow velocity profile within the tube, and boundary layer flow on the external cell surface.

The problem involving variable wall temperature may be solved by first describing the wall temperature variation as a function of flow length, and then superposing step function values that match the temperature function. To obtain the temperature distribution within the fluid, the solutions for the different wall temperature step changes must then be superposed [23, 24]. This is valid only if the governing differential equation is approximately linear, a condition which is fulfilled if the temperature variation of the fluid properties is neglected.

\subsubsection{Cooling tube flow inside the cell}

A hydrodynamically fully developed and thermally developing laminar or turbulent flow within a tube with constant wall temperature is generally known as the Graetz problem [23, 25]. These conditions are assumed to apply within the tube. The hydrodynamical entrance length is e.g. $0.03 \mathrm{~m}$ for Syltherm 800 cooling with a reference velocity of $1.4 \mathrm{~m} / \mathrm{s}$. In some of the simulations for air cooling, the flow 
is thermally developed before the air exits the cell. Some entrance lengths for various Prandtl numbers are given by Notter and Sleicher [25]. For large values of flow length $x$, the Nußelt number for the Graetz problem approximates to the solution for fully-developed laminar or turbulent flow. Equation (25) thus applies to both the thermally developing entry flow and the fully-developed flow further downstream.

The solution for a single step in wall temperature at $x=\xi$ is as follows: Before the temperature step, the wall temperature equals to the fluid inlet temperature. At the position $\xi$ where heat transfer from the wall to the fluid begins, there is a step change in wall temperature $\Delta T_{s}=T_{s}-T_{e}$ from the fluid inlet temperature $T_{e}=T(x=0, r)$ to the surface temperature $T_{s}=T_{s}\left(x=\xi, r=r_{s}\right)$. The wall heat flux for such a single step change in wall temperature is expressed in the form of an infinite eigenvalue series [23]

$$
\begin{aligned}
\dot{q}_{s, \text { step }}^{\prime \prime}\left(x^{+}\right) & =\dot{q}_{s t e p}^{\prime \prime}\left(x^{+}, r^{+}=1\right) \\
& =\frac{2 k}{r_{s}} \sum_{l=0}^{\infty} G_{l} \exp \left(-\lambda_{l}^{2}\left(x^{+}-\xi^{+}\right)\right)\left(T_{s}-T_{e}\right)
\end{aligned}
$$

where $G_{l}$ are constants and $\lambda_{l}$ are eigenvalues.

$x^{+}=\frac{2 x / D_{s}}{\operatorname{Re} \operatorname{Pr}}=\frac{2 x / D_{s}}{\operatorname{Pe}}$.

is the dimensionless axial coordinate and

$r^{+}=r / r_{s}=2 r / D_{s}$

is the dimensionless radial coordinate. Since this general solution of the Graetz problem is valid for both laminar and turbulent flow, the same applies to the expression for the heat transfer coefficient now to be derived. Eigenvalues determined by Brown [26] are used for laminar flow, and those from Notter and Sleicher [25] for turbulent flow.

As the fluid flows through the tube, the wall temperature changes at position $\xi$. The Graetz problem for the wall heat flux with variable wall temperature is solved by superposition of single wall temperature step solutions, which results in a Stieltjes integral [23, 24]:

$$
\begin{aligned}
\dot{q}_{s}^{\prime \prime}\left(x^{+}\right)= & -\frac{k}{r_{s}} \int_{0}^{x^{+}}\left(\frac{d \Theta\left(x^{+}-\xi^{+}, r^{+}\right)}{d r^{+}}\right)_{1} \frac{d T_{s}}{d \xi^{+}} d \xi^{+} \\
& -\frac{k}{r_{s}} \sum_{j=1}^{n}\left(\frac{d \Theta\left(x^{+}-\xi_{j}^{+}, r^{+}\right)}{d r^{+}}\right)_{1} \Delta T_{s, j} .
\end{aligned}
$$

$\Delta T_{s, j}$ is the wall temperature step change at position $\xi_{j}$ with the dimensionless coordinate

$\xi_{j}^{+}=\frac{2 \xi_{j} / D_{s}}{\operatorname{RePr}}=\frac{2 \xi_{j} / D_{s}}{P e}$ and

$\Theta\left(x^{+}, r^{+}\right)=\frac{T_{s}\left(x^{+}-\xi^{+}, 1\right)-T\left(x^{+}-\xi^{+}, r^{+}\right)}{T_{s}\left(x^{+}-\xi^{+}, 1\right)-T_{e}\left(\xi^{+}, r^{+}\right)}$

is the dimensionless fluid temperature for a unit step change in wall temperature.

In the Modelica numerical model, the variable wall temperature is described by the superposition of step changes in wall temperature $\left(d T_{s} / d \xi^{+}=0\right)$, and (13) may be reduced to

$\dot{q}_{s}^{\prime \prime}\left(x^{+}\right)=-\frac{k}{r_{s}} \sum_{j=1}^{n}\left(\frac{d \Theta\left(x^{+}-\xi_{j}^{+}, r^{+}\right)}{d r^{+}}\right)_{1} \Delta T_{s, j}$.

Applying the solution of the Graetz problem (10) for a single step change in wall temperature at $\xi^{+}$to (16) yields

$$
\left(\frac{d \Theta\left(x^{+}-\xi^{+}, r^{+}\right)}{d r^{+}}\right)_{1}=-2 \sum_{l=0}^{\infty} G_{l} \exp \left(-\lambda_{l}^{2}\left(x^{+}-\xi^{+}\right)\right) .
$$

The wall heat flux at position $x^{+}$is the summation over all $n$ steps between 0 and $x^{+}$:

$\dot{q}_{s}^{\prime \prime}\left(x^{+}\right)=\frac{2 k}{r_{s}} \sum_{j=1}^{n} \sum_{l=0}^{\infty} G_{l} \exp \left(-\lambda_{l}^{2}\left(x^{+}-\xi_{j}^{+}\right)\right) \Delta T_{s, j}$.

An energy balance with the simple relationship between heat flow and heat flux results in

$$
\begin{aligned}
\dot{q}_{s} & =2 \pi r_{s} \int_{0}^{x} \dot{q}_{s}^{\prime \prime}\left(x^{+}\right) d x^{+} \frac{d x}{d x^{+}} \\
& =\frac{4 \pi r_{s}^{3} u \rho c_{p}}{k} \int_{0}^{x^{+}} \dot{q}_{s}^{\prime \prime}\left(x^{+}\right) d x^{+} \\
& =\pi r_{s}^{2} u \rho c_{p}\left(T_{m}-T_{e}\right) .
\end{aligned}
$$

The difference between mean mixed temperature $T_{m}$ and inlet flow temperature $T_{e}$ is determined by evaluating (19)

$T_{m}-T_{e}=\frac{4 r_{s}}{k} \int_{0}^{x^{+}} \dot{q}_{s}^{\prime \prime}\left(x^{+}\right) d x^{+}$.

Using (18) and integrating yields

$$
T_{m}-T_{e}=8 \sum_{j=1}^{n} \sum_{l=0}^{\infty} \frac{G_{l}}{\lambda_{l}^{2}}\left[1-\exp \left(-\lambda_{l}^{2}\left(x^{+}-\xi_{j}^{+}\right)\right)\right] \Delta T_{s, j} .
$$

The surface temperature $T_{s}\left(x^{+}\right)$is calculated using the $n$ step changes $\Delta T_{s, j}$, starting from the inlet temperature $T_{e}$

$T_{S}\left(x^{+}\right)=T_{e}+\sum_{j=1}^{n} \Delta T_{s, j}$. 
The temperature difference between surface temperature $T_{s}\left(x^{+}\right)$and mean mixed temperature $T_{m}\left(x^{+}\right)$is calculated from (21) and (22):

$T_{s}-T_{m}=8 \sum_{j=1}^{n} \sum_{l=0}^{\infty} \frac{G_{l}}{\lambda_{l}^{2}} \exp \left(-\lambda_{l}^{2}\left(x^{+}-\xi_{j}^{+}\right)\right) \Delta T_{s, j}$,

since

$\sum_{l=0}^{\infty} G_{l} / \lambda_{l}^{2}=1 / 8$

The local heat transfer coefficient is defined as

$h\left(x^{+}\right)=\frac{\dot{q}_{s}^{\prime \prime}\left(x^{+}\right)}{T_{s}\left(x^{+}\right)-T_{m}\left(x^{+}\right)}$,

and calculated from the heat flux from (18) and the temperature difference from (23) to be

$h\left(x^{+}\right)=\frac{\frac{2 k}{r_{s}} \sum_{j=1}^{n} \sum_{l=0}^{\infty} G_{l} \exp \left(-\lambda_{l}^{2}\left(x^{+}-\xi_{j}^{+}\right)\right) \Delta T_{s, j}}{8 \sum_{j=1}^{n} \sum_{l=0}^{\infty} \frac{G_{l}}{\lambda_{l}^{2}} \exp \left(-\lambda_{l}^{2}\left(x^{+}-\xi_{j}^{+}\right)\right) \Delta T_{s, j}}$.

This equation is implemented in the model for laminar and turbulent tube flow with variable wall temperature.

The flow is unstable in the transition region between $R e=2300$ and $R e=10^{4}$, and fluctuates between laminar and turbulent flow. No data are available for eigenvalues in this region, so the heat transfer coefficient must be determined by some other method. Gnielinski [27] proposes the linear interpolation of mean Nußelt numbers in the transition region between the laminar Nußelt number at $R e=2300$ and the turbulent Nußelt number at $R e=10^{4}$ for the case of fully-developed flow. Accordingly the local heat transfer coefficient in the transition region is calculated as

$h\left(x^{+}\right)=(1-\gamma) h_{2300}\left(x^{+}\right)+\gamma h_{10^{4}}\left(x^{+}\right)$

where $\gamma=(\operatorname{Re}-2300) /\left(10^{4}-2300\right)$.

\subsubsection{External boundary layer flow along the cell}

The external flow along the cell is characterized as a boundary layer problem. To determine a solution for variable wall temperature, the superposition method is again used. The step response for a semi-infinite plate with unheated starting length $\xi$ is used, neglecting the curvature of the cell surface. Applying the integral method with summation over $\mathrm{n}$ steps between 0 and $x$, as in Sect. 2.5.1, but neglecting the coolant temperature change (see [22] for further details), leads to the relationship for the local heat transfer coefficient for laminar flow

$h=\frac{\sum_{j=1}^{n} \frac{0.332 k}{x} \operatorname{Pr}^{1 / 3} \operatorname{Re}_{x}^{1 / 2}\left[1-\left(\frac{\xi_{j}}{x}\right)^{3 / 4}\right]^{-1 / 3} \Delta T_{s, j}}{\sum_{j=1}^{n} \Delta T_{S, j}}$.

For further information on the derivation and background of the superposition method for variable wall temperature see Kays et al. [23] or Greif [24].

\subsubsection{Forced convection at end caps}

Free convection at the end caps achieves a relatively low heat transfer coefficient, representing a high resistance to cell cooling, since most of the heat is removed through the end caps. Increased heat removal from the end caps will reduce this thermal resistance and improve the cell temperature. Perpendicular flow towards a surface achieves high heat transfer coefficients. Only air or an oil-based coolant can be used to remove heat from the end caps with their live end connectors. The effect of forced convection from a circular nozzle is assessed on the basis of an empirical heat transfer relation from the VDI Heat Atlas, Gk 2 [13].

\subsubsection{Free convection}

Heat transfer from the cell to the coolant causes the coolant temperature to rise in the direction of flow. Since the coolant's density is temperature dependent, buoyancy effects result in fluid movement which initiates free convective heat transfer. This effect may be neglected when forced convection is applied. The three cases considered here are: free convection within the end cap enclosures, free convection within the tube, and free convection around the cylinder.

Free convective flow is initiated within the end cap enclosures (length $20.0 \mathrm{~mm}$, diameter $33.6 \mathrm{~mm}$ ). Relationships from the VDI Heat Atlas, Fc 3 [13] for heat transfer within vertical enclosures are used to calculate the resulting heat transfer coefficient.

For the flow within the internal tube, free convection is of special significance. The cell design which includes an internal tube is intended for active cooling. But to ensure that the cell can function as long as possible without active cooling, passive cooling with free convection must be at least as effective as heat conduction in the electrolyte-soaked electrode of the initial cell design. This passive cooling is negligible if the tubes are horizontal. Evaluation of the passive cooling must take coolant temperature changes into account. The heat transfer relationship for free convection from the VDI Heat Atlas, Fd 1 [13] is applied.

To determine heat transfer from the cylindrical shell, the heat transfer relationship for free convection at a vertical cylinder from the VDI Heat Atlas, Fa 2 [13] is used. 


\section{Simulation}

\subsection{Evaluation criteria}

To prevent thermal runaway of the cell due to separator melting, the temperature should under no circumstances exceed 60 to $70^{\circ} \mathrm{C}$ in any part of the cell. Regarding the long life cycle of an automobile in comparison to the life time of a state-of-the-art battery stack under normal conditions, the cell temperature should not exceed $40^{\circ} \mathrm{C}$ for any extended period of time. The optimum (volume-weighted) mean temperature range

$\bar{T}=T_{i} \frac{V_{i}}{\sum V_{i}}$

lies between 25 and $30^{\circ} \mathrm{C}$, which is a compromise between the good battery performance defined by Fick's diffusion law at high temperature and a longer battery life at low temperature. To avoid volume dilation and thus high mechanical stress within the cell, which has a negative impact on its cycle stability, the temperature difference within the cell should not exceed $10^{\circ} \mathrm{C}$.

So the benchmarks to evaluate the temperature fields are:

- Maximum temperature $<40^{\circ} \mathrm{C}$ [2]

- Minimum temperature $>-30^{\circ} \mathrm{C}[12]$

- Maximum temperature difference $<10^{\circ} \mathrm{C}$.

- Mean temperature (see (28)) 25 to $30^{\circ} \mathrm{C}$ [2]

\subsection{Baseline simulations}

Results for a cell with heat generation of $300 \mathrm{~kW} / \mathrm{m}^{3}$ and constant surface temperature $25^{\circ} \mathrm{C}$ are compared in Fig. 7 with results for a cell using forced-convection heat transfer with 38 vol.- $\%$ aqueous propylene glycol entering at $25^{\circ} \mathrm{C}$ with a flow velocity of $1 \mathrm{~m} / \mathrm{s}$ at the cylindrical shell and with free-convection heat transfer to air at the end caps. The flow direction in this and all following figures is from the bottom (negative copper end connector) to the top (positive aluminum end connector) as this flow direction leads to lower temperatures.

Table 3 shows that both the maximum temperature and the mean temperature can be reduced to the required levels if heat transfer is idealized (constant temperature) for the entire surface. The maximum temperature difference of $13.6^{\circ} \mathrm{C}$ is critical and will result in lower cycle stability owing to mechanical stress.

The equivalent comparison for lower heat generation at $200 \mathrm{~kW} / \mathrm{m}^{3}$ is presented in Table 4 . As expected, the maximum and mean temperatures lie within the required region, but the maximum temperature difference of about $11^{\circ} \mathrm{C}$ for forced convection is still too high.
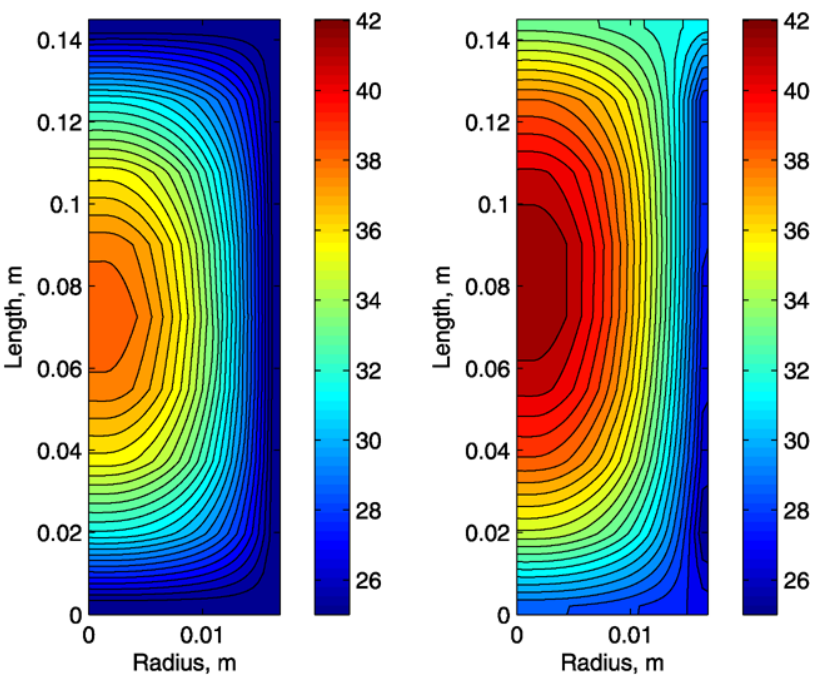

Fig. 7 Comparison of temperature fields with constant temperature boundary condition $25^{\circ} \mathrm{C}$ (left) and forced-convective heat transfer for cooling with aqueous propylene glycol, velocity $1 \mathrm{~m} / \mathrm{s}$, inlet temperature $25^{\circ} \mathrm{C}$ (right), for heat generation $g=300 \mathrm{~kW} / \mathrm{m}^{3}$

Table 3 Comparison of temperature fields for constant temperature boundary condition $25^{\circ} \mathrm{C}$ and forced convection boundary condition. A: with aqueous propylene glycol (Fig. 7), M: with Syltherm 800, reference velocity $1.0 \mathrm{~m} / \mathrm{s}$, inlet temperature $25^{\circ} \mathrm{C}$, for heat generation $g=300 \mathrm{~kW} / \mathrm{m}^{3}$

\begin{tabular}{llll}
\hline Boundary condition & $\begin{array}{l}\text { Constant } \\
\text { temperature } \\
\end{array}$ & C & \multicolumn{2}{l}{$\begin{array}{l}\text { Forced } \\
\text { convection }\end{array}$} \\
\cline { 3 - 4 } & $\mathrm{A}$ & $\mathrm{M}$ \\
\hline Maximum temperature in ${ }^{\circ} \mathrm{C}$ & 38.6 & 42.0 & 44.4 \\
Minimum temperature in ${ }^{\circ} \mathrm{C}$ & 25.0 & 25.5 & 26.6 \\
Mean temperature in ${ }^{\circ} \mathrm{C}$ & 28.9 & 32.5 & 34.8 \\
\hline
\end{tabular}

Table 4 Comparison of temperature fields with constant temperature boundary condition $25^{\circ} \mathrm{C}$ and forced-convective heat transfer for cooling with aqueous propylene glycol, velocity $1 \mathrm{~m} / \mathrm{s}$, inlet temperature $25^{\circ} \mathrm{C}$, for heat generation $g=200 \mathrm{~kW} / \mathrm{m}^{3}$

\begin{tabular}{lll}
\hline Boundary condition & $\begin{array}{l}\text { Constant } \\
\text { temperature }\end{array}$ & $\begin{array}{l}\text { Forced } \\
\text { convection }\end{array}$ \\
\hline Maximum temperature in ${ }^{\circ} \mathrm{C}$ & 34.0 & 36.4 \\
Minimum temperature in ${ }^{\circ} \mathrm{C}$ & 25.0 & 25.3 \\
Mean temperature in ${ }^{\circ} \mathrm{C}$ & 27.6 & 30.1 \\
\hline
\end{tabular}

\subsection{Forced convection at end caps}

Because most heat is removed axially, forced convection is applied to the end caps as well as to the cylindrical shell. Both end caps are cooled with 38 vol.-\% aqueous propylene glycol at a flow velocity of $1 \mathrm{~m} / \mathrm{s}$ perpendicular to the end caps. The distance between nozzle and end cap is $0.02 \mathrm{~m}$, the nozzle diameter $0.0084 \mathrm{~m}$. Results (Fig. 8) indicate that 

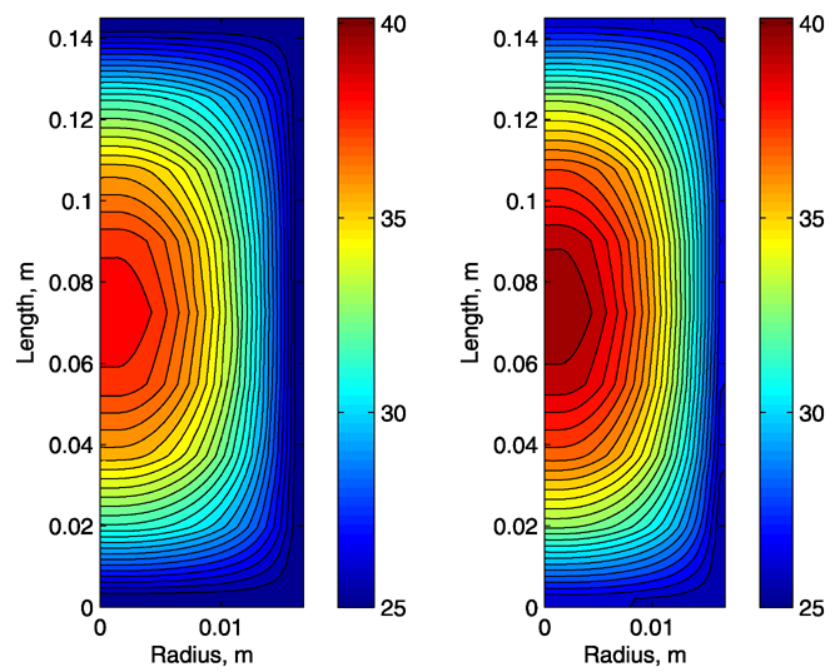

Fig. 8 Comparison of temperature fields with constant temperature boundary condition $25^{\circ} \mathrm{C}$ (left) and forced-convective heat transfer at shell and end caps with aqueous propylene glycol, velocity $1 \mathrm{~m} / \mathrm{s}$, inlet temperature $25^{\circ} \mathrm{C}$ (right), for heat generation $g=300 \mathrm{~kW} / \mathrm{m}^{3}$

forced convection at the end caps achieves a thermal performance which is very close to the idealized constant temperature boundary condition. If possible, an active cooling system should be installed on the end caps, too. The maximum temperature is slightly above the $40^{\circ} \mathrm{C}$ limit and the mean temperature somewhat higher than the $30^{\circ} \mathrm{C}$ limit (Table 5).

None of these simulations ensure a satisfactory steadystate temperature field. On the basis of earlier simulations [10], which considered thermal management only, it is appropriate to modify the cell design to support high cycle stability.
Table 5 Comparison of the temperature fields in Fig. 8

\begin{tabular}{lll}
\hline Boundary condition & $\begin{array}{l}\text { Const. } \\
\text { temperature } \\
\text { C }\end{array}$ & $\begin{array}{l}\text { Forced convection } \\
\text { at shell and end caps } \\
\text { B }\end{array}$ \\
\hline Max. temperature in ${ }^{\circ} \mathrm{C}$ & 38.6 & 40.1 \\
Min. temperature in ${ }^{\circ} \mathrm{C}$ & 25.0 & 25.6 \\
Mean temperature in ${ }^{\circ} \mathrm{C}$ & 28.9 & 30.3 \\
\hline
\end{tabular}

\subsection{Effects of thermal conductivity of the negative electrode}

The heat transfer characteristics of the cell can be further improved by increasing the thermal conductivity of internal cell components. Morris et al. [28] proposed using carbon nanotubes (CNTs) as a negative electrode because of their advantageous electrochemical and physiochemical properties, especially their high Li-ion storage capacity, which allows the cell's energy density to be increased. In addition, the high thermal conductivity of CNTs can be very beneficial to the thermal management of a Li-ion cell.

Several studies have investigated the thermal conductivity of CNTs, which range from 300 to $6000 \mathrm{~W} /(\mathrm{m} \mathrm{K})$ in axial direction $[29,30]$, depending on nanotube type and length. The off-axis thermal conductivity of CNTs, by contrast, has been found to be very low, around $1.5 \mathrm{~W} /(\mathrm{m} \mathrm{K})$ [31]. Non-oriented nanotubes have thermal conductivities of about $30 \mathrm{~W} /(\mathrm{m} \mathrm{K})$, which is still much higher than that of graphite, the material currently used. The system is analysed for four different cases (Fig. 9), in which the negative electrode is composed of graphite, non-oriented CNTs, radially-oriented CNTs, or axially-oriented CNTs, all with a constant-temperature boundary condition. Significantly improved temperatures are achieved relative to graphite (Table 6).
Fig. 9 Comparison of temperature fields of the cell with negative electrode composed of (from left to right) graphite, non-oriented CNTs, radially-oriented CNTs or axially-oriented CNTs, for constant temperature boundary condition $25^{\circ} \mathrm{C}$ and heat generation $g=300 \mathrm{~kW} / \mathrm{m}^{3}$
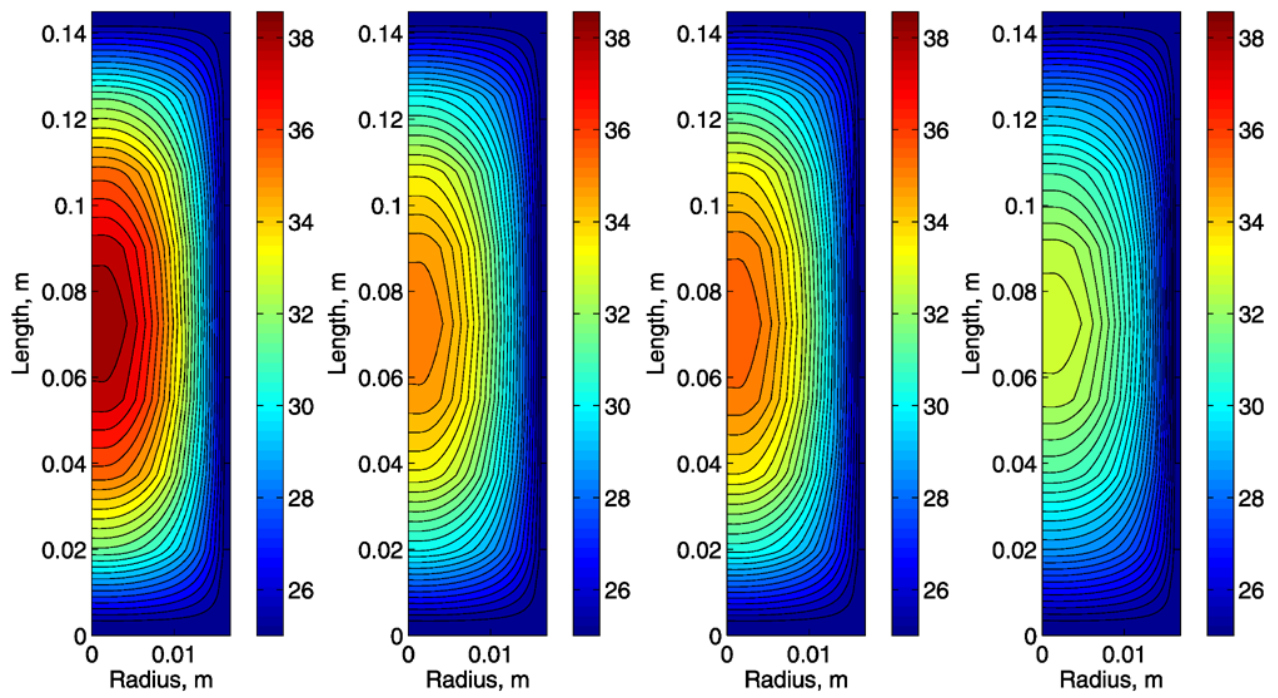
Table 6 Comparison of the temperature fields from Fig. 9 for different thermal conductivities of the negative electrode. C: Graphite, D: Non-oriented CNTs, E: Radially-oriented CNTs, F: Axially-oriented CNTs

\begin{tabular}{lllll}
\hline Anode material & $\mathrm{C}$ & $\mathrm{D}$ & $\mathrm{E}$ & $\mathrm{F}$ \\
\hline $\begin{array}{l}\text { Axial thermal conductivity } \\
\text { in W/(m K) }\end{array}$ & 1.04 & 30 & 1.5 & 300 \\
$\begin{array}{l}\text { Radial thermal conductivity } \\
\text { in W/(m K) }\end{array}$ & 1.04 & 30 & 300 & 1.5 \\
Maximum temperature in ${ }^{\circ} \mathrm{C}$ & 38.6 & 35.5 & 35.9 & 33.1 \\
Minimum temperature in ${ }^{\circ} \mathrm{C}$ & 25.0 & 25.0 & 25.0 & 25.0 \\
Mean temperature in ${ }^{\circ} \mathrm{C}$ & 28.9 & 28.0 & 28.1 & 27.3 \\
\hline
\end{tabular}

Table 7 Comparison of temperature fields with separator materials $\mathrm{PE} / \mathrm{PP}$ and PP mixed with particles of e.g. magnetite, barite, talc or copper in a ratio which results in a thermal conductivity of $1.5 \mathrm{~W} /(\mathrm{m} \mathrm{K})$, for constant temperature boundary condition $25^{\circ} \mathrm{C}$ and heat generation $g=300 \mathrm{~kW} / \mathrm{m}^{3}$

\begin{tabular}{lll}
\hline Separator material & $\mathrm{PE} / \mathrm{PP}$ & $\mathrm{PP}+$ filling material \\
Porosity & 0.50 & 0.50 \\
Thermal conductivity & 0.22 & 1.5 \\
in W/(m K) & & \\
\hline Maximum temperature in ${ }^{\circ} \mathrm{C}$ & 38.6 & 37.5 \\
Minimum temperature in ${ }^{\circ} \mathrm{C}$ & 25.0 & 25.0 \\
Mean temperature in ${ }^{\circ} \mathrm{C}$ & 28.9 & 28.6 \\
\hline
\end{tabular}

\subsection{Effects of different separator materials}

The thermal performance of the cell may also be improved by using a different separator material:

1. Polyethylene (PE) and polypropylene (PP) are standard materials for separators, which are used in previous simulations.

2. A composite material containing metal particles has an increased thermal conductivity compared to a PE/PP separator.

3. Ceramic materials are another possible choice for separators. Because separator melting is a significant safety concern, a newly-developed separator material uses ceramics to improve the safety of the cell, thus making it more suitable for use in HEVs. The thermal conductivities of ceramics are not always higher than those of standard separators.

4. A ceramic separator containing metal particles has an increased thermal conductivity, too [32].

These different separator materials are investigated here.

Values for the thermal conductivity of polypropylene mixed with different metals have been reported by Weidenfeller et al. [33]. Filler materials such as magnetite, barite, talc or copper can increase the thermal conductivity to $1.5 \mathrm{~W} /(\mathrm{m} \mathrm{K})$ or more, according to the proportion of
Table 8 Comparison of temperature fields with separator materials Separion (left), $\mathrm{Al}_{2} \mathrm{O}_{3}$ with Cr-particles (centre) and the cermet $\mathrm{BeO}+$ $\mathrm{Be}+\mathrm{Si}$ (right), for constant temperature boundary condition $25^{\circ} \mathrm{C}$ and heat generation $g=300 \mathrm{~kW} / \mathrm{m}^{3}$

\begin{tabular}{llll}
\hline Separator material & $\begin{array}{l}\text { Separion } \\
\text { Porosity }\end{array}$ & $\begin{array}{l}\mathrm{Al}_{2} \mathrm{O}_{3}+\mathrm{Cr} \\
0.50\end{array}$ & $\begin{array}{l}\mathrm{BeO}+\mathrm{Be}+\mathrm{Si} \\
0.50\end{array}$ \\
$\begin{array}{l}\text { Thermal conductivity } \\
\text { in W/(m K) }\end{array}$ & 0.01 & 0.962 & 1.89 \\
\hline Max. temp. in ${ }^{\circ} \mathrm{C}$ & 39.1 & 37.8 & 37.4 \\
Min. temp. in ${ }^{\circ} \mathrm{C}$ & 25.0 & 25.0 & 25.0 \\
Mean temp. in ${ }^{\circ} \mathrm{C}$ & 29.0 & 28.6 & 28.5 \\
\hline
\end{tabular}

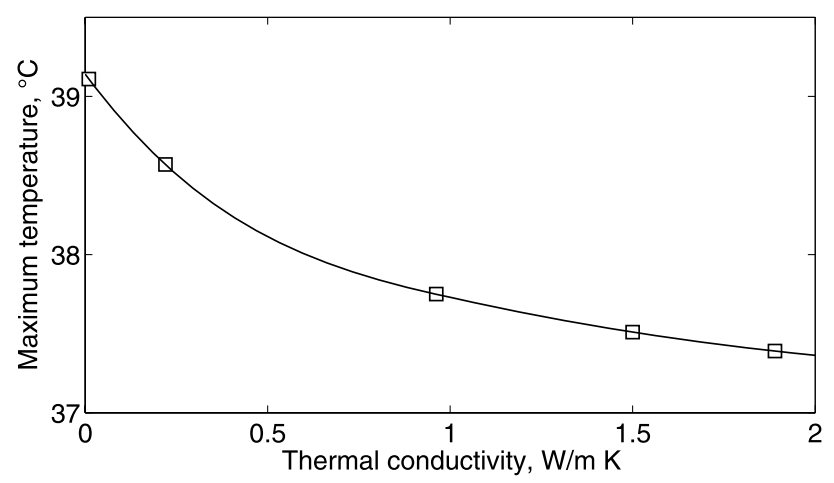

Fig. 10 Maximum temperature in the cell as a function of thermal conductivity of the separator material

filler material. All separators are assumed to have the same porosity of 0.50 . Table 7 shows that the maximum temperature difference is reduced by about $1{ }^{\circ} \mathrm{C}$, which only slightly improves the temperature field. It should be noted that there may be a negative impact upon electrochemical performance due to the metal particles. This simulation considers thermal management only.

Yamane et al. [34] report the thermal conductivity of silicon oxide to be independent of the layer thickness if this exceeds $1 \mu \mathrm{m}$. The same is assumed to apply to an aluminum oxide composite. The thermal conductivity of $0.01 \mathrm{~W} /(\mathrm{m} \mathrm{K})$ for a mixture of both materials is taken from CINDAS Thermophysical Properties of Matter Database [35] and is applied to the Separion separator. Use of a cermet material (a composite of ceramic and metal) can achieve a thermal conductivity of $0.962 \mathrm{~W} /(\mathrm{m} \mathrm{K})$ for a composite of 70 mass- $\%$ aluminum oxide and 30 mass- $\%$ chromium [35]. Another cermet composite of beryllium oxide, beryllium and silicon has an even higher thermal conductivity of $1.89 \mathrm{~W} /(\mathrm{m} \mathrm{K})$ [35], and can therefore enhance heat removal from the cell. Temperature values for the three different ceramic materials are displayed in Table 8 . The dependence of the maximum cell temperature upon separator thermal conductivity is illustrated in Fig. 10. 


\subsection{Variation of cell geometry}

A change in cell geometry redistributes its thermal resistances and thus changes the temperature distribution within the cell. Though many different cell geometries are possible, most cells are produced in the standardized 18650 size, of diameter $18 \mathrm{~mm}$ and length $65 \mathrm{~mm}$. This size was introduced early in Li-ion cell development, when the thermal performance was unlikely to have been considered. Nowadays, Li-ion cells in many different sizes are under development for use in HEVs. In the following simulations, the cell active volume is kept constant while varying the geometry.

\subsubsection{Variation of cell length and diameter}

One possible change in cell design is the variation of cell length or diameter. The temperature distribution could also be improved by changing the thickness of the various layers, but this would affect the fundamental electrochemical design and should therefore not be considered for optimizing the temperature distribution, especially as the variation of layer thickness is significant when designing either high energy or high power cells. In these simulations, the cell active volume is halved first axially and then radially. Figure 11 and Table 9 show that, even for high heat generation, the temperature criteria can be fulfilled. It should be noted that shorter cells perform significantly better than reduced-radius cells, because axial heat removal predominates.

Table 9 Comparison of the temperature fields in Fig. 11

\begin{tabular}{llll}
\hline Cell dimensions in mm & $145 \times 33.6$ & $72.5 \times 33.6$ & $145 \times 24$ \\
\hline Max. temperature in ${ }^{\circ} \mathrm{C}$ & 38.6 & 30.9 & 33.1 \\
Min. temperature in ${ }^{\circ} \mathrm{C}$ & 25.0 & 25.0 & 25.0 \\
Mean temperature in ${ }^{\circ} \mathrm{C}$ & 28.9 & 26.9 & 27.3 \\
\hline
\end{tabular}
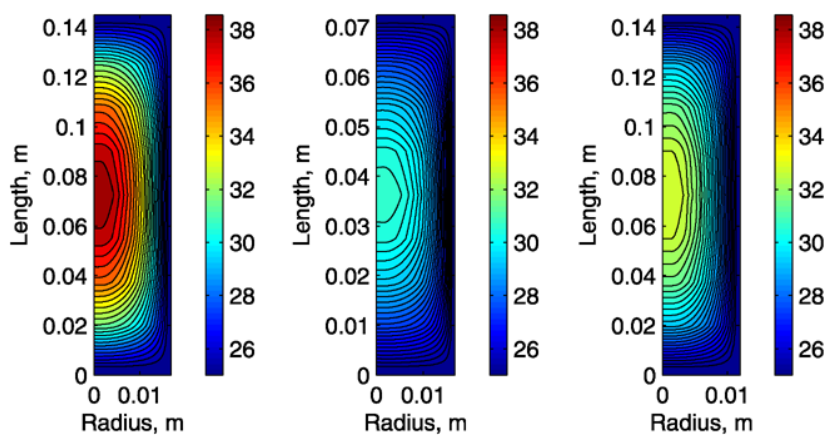

Fig. 11 Comparison of temperature fields of the cell with $33.6 \mathrm{~mm}$ diameter and $145 \mathrm{~mm}$ length (left), $33.6 \mathrm{~mm}$ diameter and reduced length of $72.5 \mathrm{~mm}$ (centre), and reduced diameter of $24.0 \mathrm{~mm}$ and $145 \mathrm{~mm}$ length (right), for constant temperature boundary condition $25^{\circ} \mathrm{C}$ and heat generation $g=300 \mathrm{~kW} / \mathrm{m}^{3}$

\subsubsection{New cell design with internal cooling tube}

The usefulness of an internal cooling tube in a new cell design was assessed by several simulations. In this section, the influence of tube diameter $D_{s}$ upon temperature distribution is first shown for cooling with air, and then for cooling with the silicone oil Syltherm 800. As indicated in Sect. 2.4, cells with an internal cooling tube are cooled by an internal flow in addition to external flow along the cylindrical shell. All cells have the same active volume. For each diameter, the same power is used to transport the coolant.

The cell core temperature is particularly high, therefore the cooling tube passes through this region to remove some of the heat by convection. This hot spot would be inaccessible in the absence of the cooling tube, and the heat would need to be conducted through the cell with a larger temperature gradient.

Cooling with air Temperature distributions for air cooling with various tube diameters and a reference flow velocity of $12 \mathrm{~m} / \mathrm{s}$ are shown in Fig. 12. The reference flow velocity is defined as the flow velocity in an internal tube of diameter $D_{s}=1.92 \mathrm{~mm}$. These simulations use heat generation $g=300 \mathrm{~kW} / \mathrm{m}^{3}$ and a coolant temperature of $25^{\circ} \mathrm{C}$ at the flow inlet. The simulations without an internal cooling tube $\left(D_{s}=0 \mathrm{~mm}\right)$ and with an internal cooling tube of $D_{s}=1.92 \mathrm{~mm}$ both have the same cell casing outer radius, and are thus comparable. The maximum, minimum and mean temperatures of the cell are displayed in Fig. 13 as a function of the internal cooling tube diameter $D_{s}$. Even for the smallest tube diameter, the internal cooling tube results in a temperature decrease. The low heat capacity of the
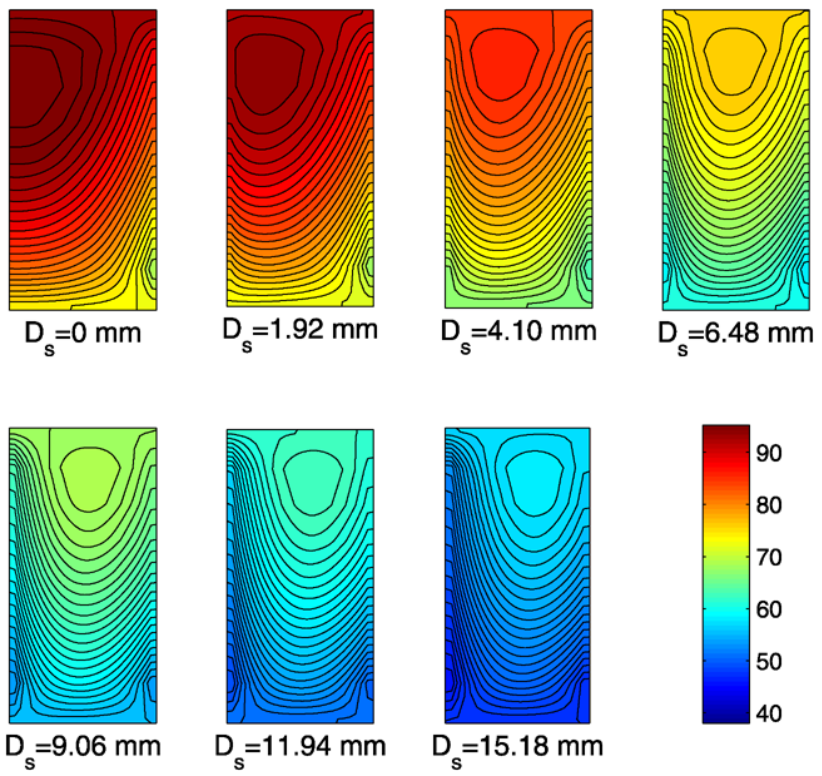

$D_{\mathrm{s}}=6.48 \mathrm{~mm}$

Fig. 12 Temperature field of the cell for different cooling tube diameters $D_{s}$ for cooling with air at reference flow velocity $12 \mathrm{~m} / \mathrm{s}$, for inlet temperature $25^{\circ} \mathrm{C}$ and heat generation $g=300 \mathrm{~kW} / \mathrm{m}^{3}$ 


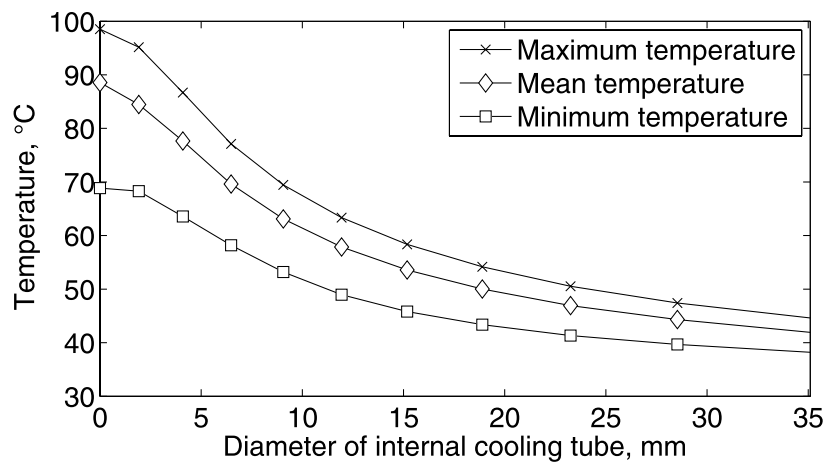

Fig. 13 Maximum, minimum and mean temperature of the cell as a function of tube diameter $D_{s}$ for cooling with air at reference flow velocity of $12 \mathrm{~m} / \mathrm{s}$, for inlet temperature $25^{\circ} \mathrm{C}$ and heat generation $g=300 \mathrm{~kW} / \mathrm{m}^{3}$

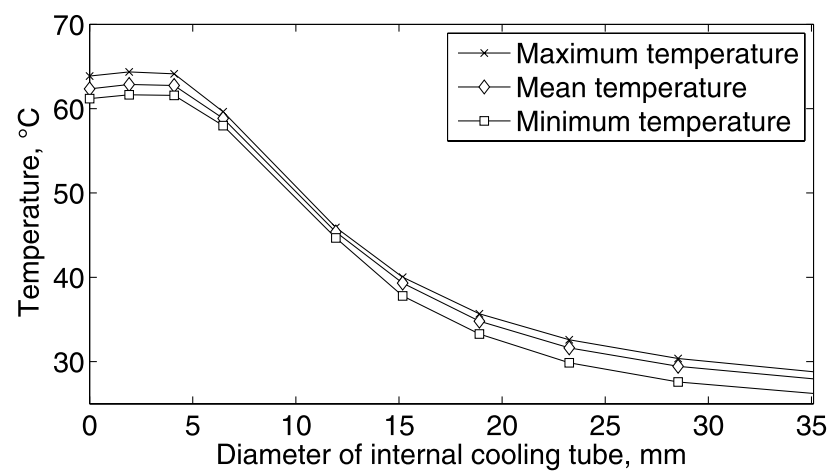

Fig. 14 Maximum, minimum and mean temperature of the cell as a function of tube diameter $D_{s}$ with free-convective air cooling both within the cooling tube and at the shell, for inlet temperature $25^{\circ} \mathrm{C}$ and heat generation $g=50 \mathrm{~kW} / \mathrm{m}^{3}$

air flow limits the amount of heat transferred, especially for small cooling tube diameters, where the cell temperature exceeds the temperature threshold for thermal runaway.

Since the active cooling system may not always be in operation, passive cooling must be evaluated, too. Simulations for an air temperature of $25^{\circ} \mathrm{C}$ with free convection within a vertical cell are shown in Fig. 14 for a lower heat generation $g=50 \mathrm{~kW} / \mathrm{m}^{3}$. The first two simulations with an internal tube result in slightly higher temperatures, indicating that conduction in electrolyte and electrode removes more energy than does free convection for this cell size. Although the new cell design reduces temperatures to a level at which thermal runaway no longer occurs, air cooling cannot be recommended, as none of the temperature benchmarks are met for heat generation $g=300 \mathrm{~kW} / \mathrm{m}^{3}$.

Cooling with silicone oil Syltherm 800 Figure 15 shows the change in temperature distribution for cooling with silicone oil Syltherm 800 at an inlet temperature of $25^{\circ} \mathrm{C}$ and a reference flow velocity of $1.4 \mathrm{~m} / \mathrm{s}$, for various cooling tube diameters $D_{s}$. The dependence of maximum, minimum and
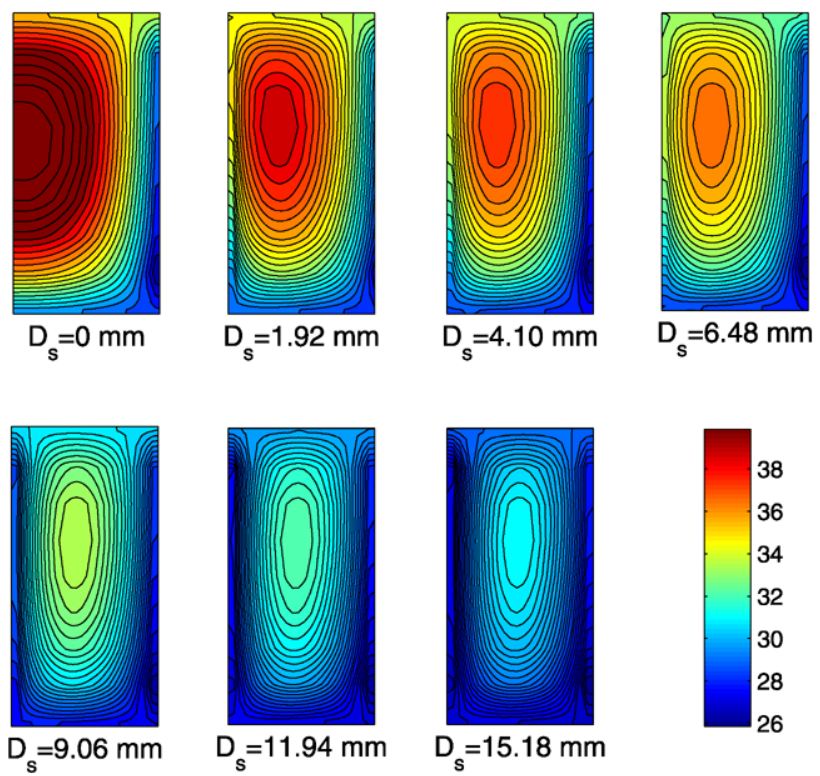

Fig. 15 Temperature field of the cell for different cooling tube diameters $D_{s}$ for cooling with Syltherm 800 at reference flow velocity $1.4 \mathrm{~m} / \mathrm{s}$, for inlet temperature $25^{\circ} \mathrm{C}$ and heat generation $g=300 \mathrm{~kW} / \mathrm{m}^{3}$

mean cell temperatures upon the cooling tube diameter is shown in Figs. 16, 17 and 18.

The improvement resulting from the cooling tube is seen by comparing the results at $D_{s}=0 \mathrm{~mm}$ and $D_{s}=1.92 \mathrm{~mm}$. These are in agreement with results for the one-dimensional model (Fig. 6), where the convective heat transfer for simulations with air or Syltherm 800 removes more heat than does conduction in the graphite electrode of the original cell design. Because of the considerable difference between minimum required and actual heat transfer coefficient (factor $>50$ ) for the two designs (with and without cooling tube), the one-dimensional approximation used for Fig. 6 is sufficient to demonstrate that the new cell design leads to a lower temperature. The heat transfer coefficient increases only slightly with the tube diameter, whilst the thermal resistance decreases.

The flow volume along the cylindrical shell and within the cooling tube increases with cooling tube diameter and flow velocity, e. g. by about $30 \%$ between the simulations with $u_{r e f}=0.8 \mathrm{~m} / \mathrm{s}$ and $1.4 \mathrm{~m} / \mathrm{s}$, whilst the temperature decreases only slightly. As conduction represents a higher portion of the thermal resistance relative to convection, temperature is more sensitive to geometry than to flow volume or velocity variation.

In order to achieve significant temperature reduction and to avoid negative effects relative to the standard cell design for free convection, the minimum cooling tube diameter is set at $6.48 \mathrm{~mm}$. To ensure a plausible cell geometry, the maximum tube diameter is set at $18.9 \mathrm{~mm}$. The maximum temperature is thus reduced by between $7^{\circ} \mathrm{C}$ and $13.8^{\circ} \mathrm{C}$. The 


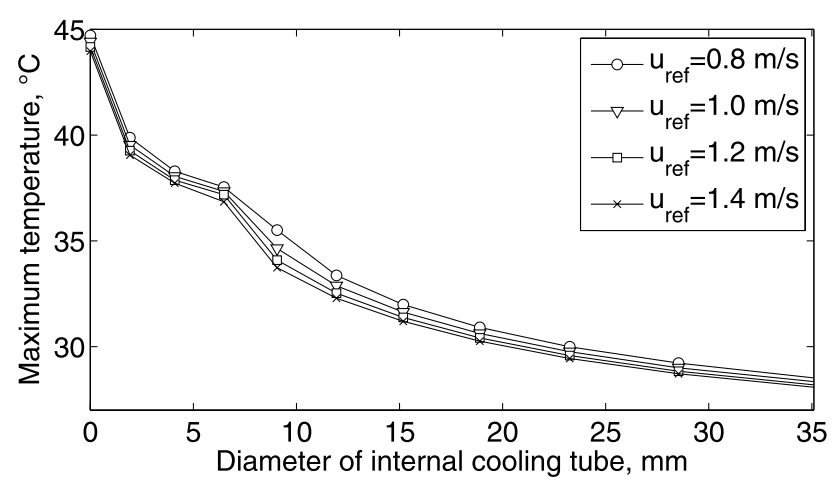

Fig. 16 Maximum temperature of the cell as a function of cooling tube diameter $D_{s}$ at different reference velocities for cooling with Syltherm 800 and forced convection at both cooling tube and cylindrical shell, for inlet temperature $25^{\circ} \mathrm{C}$ and heat generation $g=300 \mathrm{~kW} / \mathrm{m}^{3}$

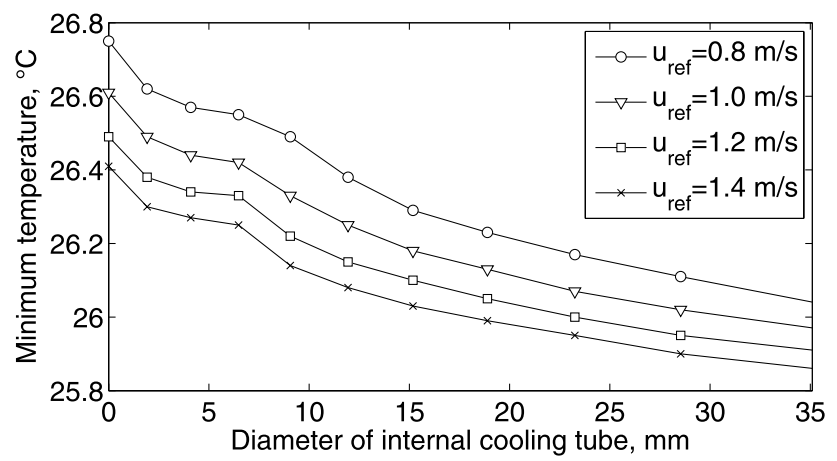

Fig. 17 Minimum temperature of the cell as a function of cooling tube diameter $D_{s}$ at different reference velocities for cooling with Syltherm 800 and forced convection at both cooling tube and cylindrical shell, for inlet temperature $25^{\circ} \mathrm{C}$ and heat generation $g=300 \mathrm{~kW} / \mathrm{m}^{3}$

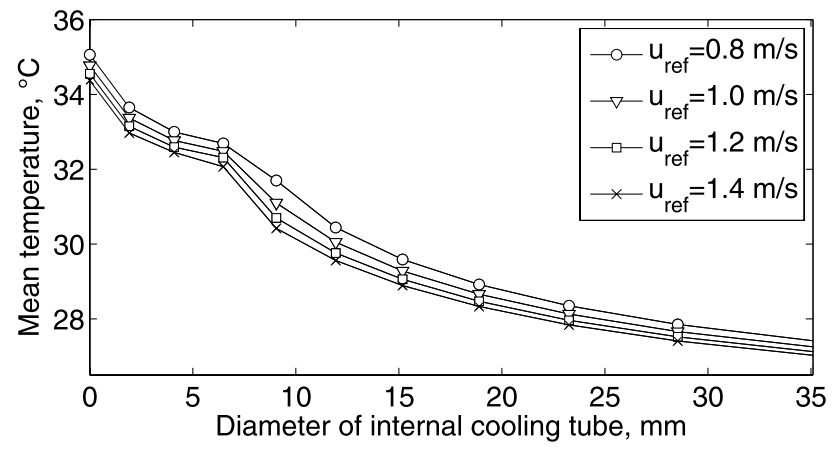

Fig. 18 Mean temperature of the cell as a function of cooling tube diameter $D_{s}$ at different reference velocities for cooling with Syltherm 800 and forced convection at both cooling tube and cylindrical shell, for inlet temperature $25^{\circ} \mathrm{C}$ and heat generation $g=300 \mathrm{~kW} / \mathrm{m}^{3}$

minimum temperature, which is close to the fluid inlet temperature, decreases by less than $1^{\circ} \mathrm{C}$. A reduction in mean temperature thus lies between $2.3^{\circ} \mathrm{C}$ and $6.1^{\circ} \mathrm{C}$.
Solid rod inside cell Filling the internal tube with a solid material of high thermal conductivity, such as copper or aluminum, is superior to air cooling only if the tube diameter is less than approximately $10 \mathrm{~mm}$ for aluminum and $5 \mathrm{~mm}$ for copper, see Fig. 6. In the case of Syltherm 800, even a copper rod of any diameter is less effective than a cooling tube. For example a cooling tube of $1.92 \mathrm{~mm}$ inner diameter and $0.48 \mathrm{~mm}$ wall thickness can be replaced by a copper rod of $2.88 \mathrm{~mm}$ diameter, whose simulation leads to maximum, minimum and mean cell temperatures of $42.7^{\circ} \mathrm{C}, 26.6^{\circ} \mathrm{C}$ and $34.6^{\circ} \mathrm{C}$, respectively. These temperatures are lower than for the original cell design, but higher than those achieved with an internal cooling tube.

Comparison with other results The simulations for an internal cooling tube employ convective boundary conditions. Within the cooling tube, the fluid temperature varies significantly more than does the external flow temperature. In the simulations of the original cell design, the fluid temperature varies little, and the wall temperature is almost constant (cf. Fig. 7), so constant temperature boundary conditions could be assumed. Because of these different boundary conditions used for simulations of the old and new cell designs, direct comparison of the simulation results is difficult. Therefore reductions in maximum and mean temperatures are presented non-dimensionalized by the temperature difference between maximum/mean baseline temperature and fluid inlet temperature. Baseline model temperatures are taken from Table 3 and Figs. 16 and 18 at $D_{s}=0 \mathrm{~mm}$. Resulting dimensionless improvements in temperatures are shown in Tables 10 and 11 . When the cooling tube diameter is small, the improvement is of the same order as is achieved by other proposed modifications. For large tube diameters, however, the internal tube design exceeds the performance of the other modifications.

\section{Conclusion}

The temperature benchmarks defined in Sect. 3.1 are used to assess the temperature distribution.

Table 10 Dimensionless temperature reduction for various internal cooling tube diameters $D_{s}$. Cooling with Syltherm 800, reference velocity $u_{r e f}=1 \mathrm{~m} / \mathrm{s}$, inlet temperature $25^{\circ} \mathrm{C}$, for heat generation $g=300 \mathrm{~kW} / \mathrm{m}^{3}$

\begin{tabular}{lll}
\hline $\begin{array}{l}\text { Tube diameter } D_{s}, \\
\mathrm{~mm}\end{array}$ & $\begin{array}{l}\text { Reduction in } \\
\text { max. temperature }\end{array}$ & $\begin{array}{l}\text { Reduction in } \\
\text { mean temperature }\end{array}$ \\
\hline 6.48 & 0.37 & 0.23 \\
9.10 & 0.50 & 0.38 \\
11.94 & 0.59 & 0.48 \\
15.18 & 0.66 & 0.57 \\
18.90 & 0.71 & 0.63 \\
\hline
\end{tabular}


Table 11 Dimensionless temperature reduction for other modifications with constant temperature boundary condition

\begin{tabular}{lll}
\hline Measure & $\begin{array}{l}\text { Reduction in } \\
\text { max. temp. }\end{array}$ & $\begin{array}{l}\text { Reduction in } \\
\text { mean temp. }\end{array}$ \\
\hline Reduced length, Table 9 & 0.56 & 0.52 \\
Reduced radius, Table 9 & 0.41 & 0.40 \\
Non-oriented CNTs, Table 6 & 0.22 & 0.22 \\
Radially oriented CNTs, Table 6 & 0.20 & 0.20 \\
Axially oriented CNTs, Table 6 & 0.40 & 0.40 \\
Aluminum rod, $D_{s}=2.88 \mathrm{~mm}$ & 0.06 & 0.01 \\
\hline
\end{tabular}

The comparison of results in Fig. 19 leads to some important conclusions for thermal management of the cell. Results for aqueous propylene glycol cooling (Col. A) show that the baseline cell design cannot operate within the desired temperature limits. Active cooling at both the cylindrical shell and the end caps (Col. B) reduces the temperature, but still does not achieve the temperature requirements. Perfect cooling (constant temperature boundary condition, Col. C) achieves the permissible maximum and mean temperatures, but the temperature difference of $13.6^{\circ} \mathrm{C}$ within the cell exceeds the limit. Cell design modification is therefore necessary.
Results of modified cell designs are compared to the baseline cell with idealized constant temperature boundary condition (Col. C.) A CNT negative electrode leads to significantly lower temperatures. Both non-oriented (Col. D) and radially-oriented CNTs (Col. E) lead to similar temperature reductions. Non-oriented CNTs are likely to be less costly, making them an attractive option. However, axiallyoriented CNTs (Col. F) lead to even lower temperatures, which fulfill the maximum temperature difference requirement, in contrast to non-oriented and axially-oriented CNTs.

Because the PP/PE separator is the cell layer with the lowest thermal conductivity, alternative separator materials are investigated. The Separion separator has attracted attention for greatly increasing the thermal safety of the cell. However, the thermal conductivity of this aluminum oxide layer is even lower than of PP/PE, and adversely affects the temperature (Col. G). The effect of introducing metal particles to increase the thermal conductivity was therefore examined. This modification achieves a slight temperature reduction (Col. H) relative to the baseline cell (Col. C).

A change in cell geometry-halving the cell active volume and therefore leading to a higher number of cellsgreatly lowers the temperature and the temperature difference. Shortening the cell yields significantly better results $(\mathrm{Col} . \mathrm{J})$ than are achieved by reducing its diameter $(\mathrm{Col}$. I). Heat is predominantly removed axially because of the

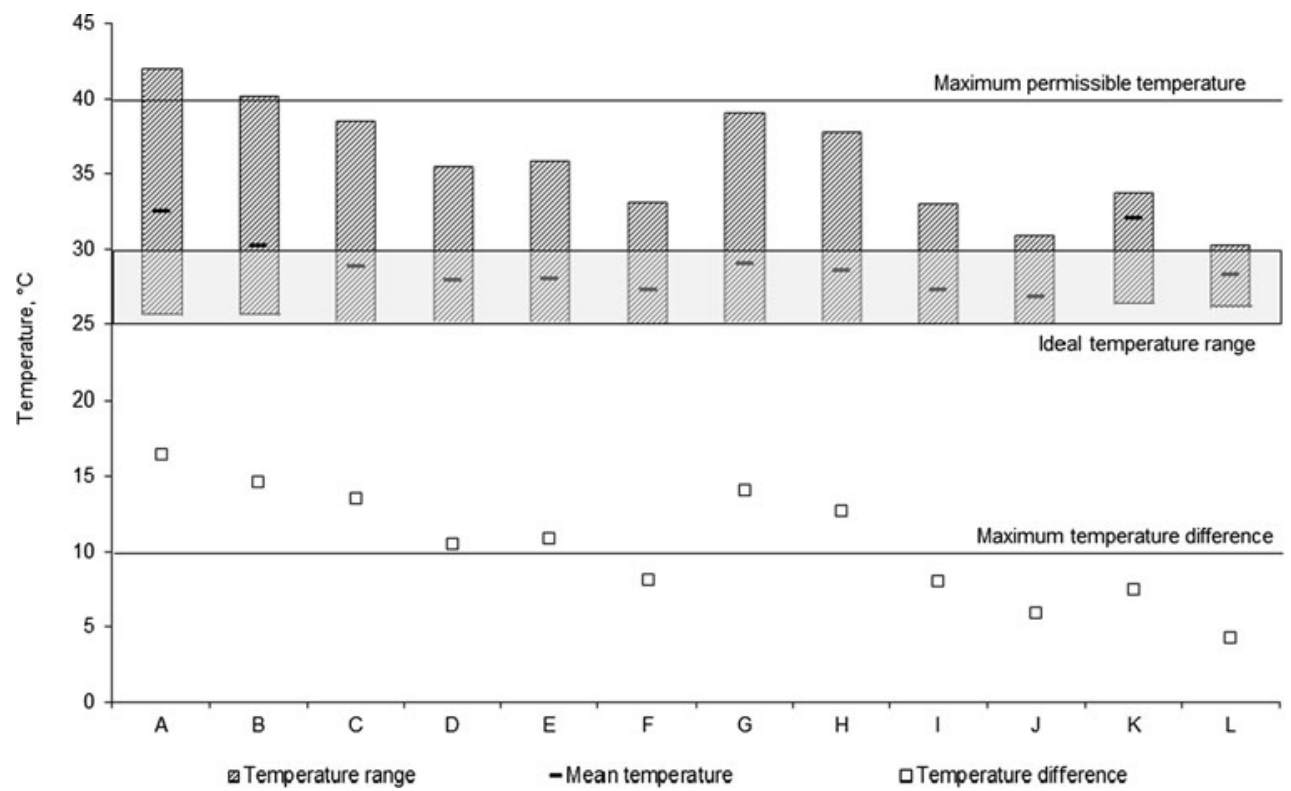

Fig. 19 Comparison of analyses with heat generation $g=300 \mathrm{~kW} / \mathrm{m}^{3}$. Col. A: Cooling with aqueous propylene glycol at cylindrical shell, Fig. 7 (right); Col. B: Cooling with aqueous propylene glycol at cylindrical shell and end caps, Fig. 8 (right); Col. C: Constant temperature boundary $25^{\circ} \mathrm{C}$, Fig. 7 (left); Col. D: Non-oriented CNTs as negative electrode, Fig. 9 (left centre); Col. E: Radially-oriented CNTs as negative electrode, Fig. 9 (right centre); Col. F: Axially-oriented CNTs as negative electrode, Fig. 9 (right); Col. G: Separion separator, Ta- ble 8; Col. $\mathrm{H}: \mathrm{Al}_{2} \mathrm{O}_{3}+\mathrm{Cr}$ as separator, Table 8; Col. I: Reduced cell diameter, Fig. 11 (right), Col. J: Reduced cell length, Fig. 11 (centre), Col. $K$ : Internal cooling tube with diameter $D_{s}=6.48 \mathrm{~mm}$, $u_{r e f}=1.4 \mathrm{~m} / \mathrm{s}$, Figs. 16, 17, 18, Col. $L$ : Internal cooling tube with diameter $D_{s}=18.9 \mathrm{~mm}, u_{\text {ref }}=1.4 \mathrm{~m} / \mathrm{s}$, Figs. 16, 17, 18. Col. $C$ to J: Perfect heat transfer, Col. $K, L$ : Convective heat transfer with Syltherm 800 at cylindrical shell and internal cooling tube 
anisotropic thermophysical properties of the cell's internals. Therefore cell design changes which enhance axial heat removal are the more effective. Both designs fulfill all evaluation criteria. The price of this advantage is a more complex electrical management, as a higher number of cells is needed to achieve a particular voltage or capacity.

All the above modifications have disadvantages: The use of new nano materials adds to the cell cost; the reduction of active volume per cell increases the complexity of electrical management and increases the passive material costs. One modification that can significantly reduce cell temperature at marginally increased cost is a cell design with an internal cooling tube. Heat is removed directly from the hottest spot in the cell, which significantly improves the temperature distribution.

Simulations have been conducted for several tube diameters and coolant velocities. The temperature benchmarks cannot be achieved by air cooling, though the improvements are considerable. Tubes of $6.48 \mathrm{~mm}$ to $18.90 \mathrm{~mm}$ internal diameter are recommended for cooling with silicone oil Syltherm 800 (Col. K, L). The temperature reduction is greater than can be achieved by the use of new materials, and is of the same order as the reduction achieved by changing the cell length. This design has some advantages over the other modifications: All temperature requirements are fulfilled. The complexity of electrical management is unaffected. Additional costs for extra casing material are acceptable. A disadvantage is the reduction of the volumetric energy and power of the cell by about 4 to $26 \%$ (according to tube diameter), though power and energy density remain nearly unchanged.

The cell design modifications using axially oriented CNTs, a reduced active volume or an internal cooling tube result in an improved temperature distribution in the cell below the given limits.

Acknowledgements This work was supported by the German Academic Exchange Service (DAAD) sponsoring M. Sievers' visit to the University of California at Berkeley.

Open Access This article is distributed under the terms of the Creative Commons Attribution Noncommercial License which permits any noncommercial use, distribution, and reproduction in any medium, provided the original author(s) and source are credited.

\section{References}

1. Asakura K, Shimomura M, Shodai T (2003) Study of life evaluation methods for Li-ion batteries for backup applications. J Power Sources 119-121:902-905

2. Jossen A, Weydanz A (2006) Moderne Akkumulatoren richtig einsetzen. Reichert, Untermeitingen

3. United States Council for Automotive Research (2002) FreedomCAR energy storage system performance goals for powerassist hybrid electric vehicles. www.uscar.org/commands/files_ download.php?files_id=25, accessed March 2009
4. Patil PG (2008) Developments in lithium-ion battery technology in The Peoples Republic of China. ANL/ESD/08-1, Transportation Technology Research and Development Center, Energy Systems Division, Argonne National Laboratory, Argonne, IL

5. Lukic SM, Khateeb SA, Al-Hallaj S, Selman JR, Emadi A (2003) On the suitability of a new high-power lithium ion battery for hybrid electric vehicle applications. SAE Int 112:49-53

6. Brotz F, Isermeyer T, Pfender C, Heckenberger T (2007) Kühlung von Hochleistungsbatterien für Hybridfahrzeuge. ATZ, Automobiltech Z 111:1156-1162

7. Sanyo lithium ion rechargable batteries. SANYO Electric Co., Ltd, Sumoto-City, Hyogo, Japan 2009. http://batteries.sanyo -component.com/fileadmin/EDITORS/BATTERIES/industrial/ catalogues/LithiumIon_2009_E_2_.pdf, accessed June 2010

8. Lewis RW, Nithiarasu P, Seetharamu KN (2004) Fundamentals of the finite element method for heat and fluid flow. Wiley, Hoboken

9. The Modelica Association, Linköping, Sweden (2007) Modelica-a unified object-oriented language for physical systems modeling language specification, version 3.0

10. Sievers M (2008) Modellierung der Temperaturverteilung in Lithium-Ionen-Batterien mit der Finite-Elemente-Methode. Bachelor's thesis, Department of Mechanical Engineering, Hamburg University of Technology

11. Krueger I, Sievers M, Schmitz G (2009) Thermal modeling of automotive lithium-ion cells using the finite element method. In: Casella F (ed) Proceedings of the 7th Int Modelica Conf, Como, Italy, 20-22 September 2009. Linköping University Electronic Press, Linköping. doi:10.3384/ecp09430072

12. Datasheet of Lithium-Ion Cell 7.5 Ah UHP-341450 (2008). GAIA Akkumulatorenwerke GmbH, Nordhausen, Germany

13. VDI-Wärmeatlas (2006) Berechnungsblätter für den Wärmeübergang, 10th edn. Editor: Verein Deutscher Ingenieure, VDIGesellschaft Verfahrenstechnik und Chemieingenieurwesen (GVC). Springer, Berlin

14. Al-Hallaj S, Maleka H, Hong JS, Selman JR (1999) Thermal modeling and design considerations of lithium-ion batteries. J Power Sources 83:1-8

15. Wu MS, Liu KH, Wang YY, Wan CC (2002) Heat dissipation design for lithium ion batteries. J Power Sources 109:160-166

16. Chen Y, Evans JW (1996) Thermal analysis of lithium-ion batteries. J Electrochem Soc 143:2708-2712

17. Julien C, Stoynov Z (2000) Materials for lithium-ion batteries. In: Proc NATO advanced study institute on materials for lithium-ion batteries, design and optimization, Sozopol, Bulgaria, September 21-October 1, 1999. Kluwer Academic, Dordrecht

18. Chen SC, Wang YY, Wan CC (2006) Thermal analysis of spirally wound lithium batteries. J Electrochem Soc 153:A637-A648

19. Gibbard HF (1978) Thermal properties of battery systems. J Electrochem Soc 125:353-358

20. Bernardi D, Pawlikowski E, Newman J (1985) A general energy balance for battery systems. J Electrochem Soc 132:5-12

21. Herwig H (2008) Strömungsmechanik: Einführung in die Physik von technischen Strömungen. Vieweg-Teubner, Wiesbaden

22. Sievers M (2009) Modeling thermal performance of new Li-ion cell designs for application in hybrid and full electric vehicles. Individual Research, Department of Mechanical Engineering, University of California at Berkeley

23. Kays W, Crawford M, Weigand B (2005) Convective heat and mass transfer, 4th edn. McGraw-Hill, New York

24. Greif R (2009) Lecture notes for heat convection (ME252). Department of Mechanical Engineering, University of California at Berkeley

25. Notter RH, Sleicher CH (1972) A solution to the turbulent Graetz problem, III: fully developed and entry region heat transfer rates. Chem Eng Sci 27:2073-2093

26. Brown GM (1960) Heat or mass transfer in a fluid in laminar flow in a circulat or flat conduit. AIChE J 6:179-183 
27. Gnielinski V (1995) Ein neues Berechnungsverfahren für die Wärmeübertragung im Übergangsbereich zwischen laminarer und turbulenter Rohrströmung. Forsch Ingenieurwes 61:240-248

28. Morris RS, Dixon BG, Gennett T, Raffaelle R, Heben MJ (2005) High-energy, rechargeable Li-ion battery based on carbon nanotube technology. J Power Sources 138:277

29. Choi TY, Poulikakos D, Tharian J, Sennhauser U (2006) Measurement of the thermal conductivity of individual carbon nanotubes by the four-point three-omega method. Nano Lett 6:1589-93

30. Lukes JR, Zhong H (2007) Thermal conductivity of individual single-wall carbon nanotubes. Trans Amer Soc Mech Eng, J Heat Transf 129:705-716

31. Sinha S, Barjami S, Iannacchione G, Schwab A, Muench G (2005) Off-axis thermal properties of carbon nanotube films. J Nanopart Res 7:651-657
32. Ceramics by the Yard (2005) DEGUSSA Magazine 02:4. www. creavis.com/files/Ceramics_by_the_Yard.pdf, accessed March 2009

33. Weidenfeller B, Höfer M, Schilling FR (2004) Thermal conductivity, thermal diffusivity, and specific heat capacity of particle filled polypropylene. Composites, Part A, Appl Sci Manuf 35:423-429

34. Yamane T, Nagai N, Katayama SI, Todoki M (2002) Measurement of thermal conductivity of silicon dioxide thin films using a $3 \omega$ method. J Appl Phys 91:9772-9776

35. CINDAS, LLC. The thermophysical properties of matter database (TPMD). https://cindasdata.com, accessed March 2009 